\title{
POLINIZAÇÃO ENTOMÓFILA EM POMAR DE SEMENTES CLONAL DE Eucalyptus grandis HILL EX MAIDEN NA REGIÃO DE BOTUCATU - SP
}

JORGE MITIYO MAÉDA

Engenheiro Florestal

Orientador: Prof. PAULO YOSHIO KAGEYAMA

Dissertaçāo apresentada à Escola Superior de Agricultura "Luiz de Queiroz", da Universidade de Sāo Paulo, para obtençāo do título de

Mestre em Ciências Florestais.

\author{
PIRACICABA \\ Estado de São Paulo - Brasil \\ Dezembro - 1987
}


Maēda, Jorge Mitiyo

M184p Polinização entomófila em pomar de sementes clonal de Eucalyptus grandis Hill ex Maiden na região de Botucatu - SP. Piracicaba, 1987.

91p. ilus.

Diss. (Mestre) - ESALQ

Bibliografia

1. Eucalipto - Semente - Polinização 2. In seto polinizador 3. Polinização 4. Pomar de eucalipto - Polinização 5. Semente - Poliniza ção I. Escola Superior de Agricultura Luiz dē Queiroz, Piracicaba

$\operatorname{CDD} \quad 634.9734$ 
POLINIZAÇÃO ENTOMÓFILA EM POMAR DE SEMENTES CLONAL DE Eucalyptus grandis Hill ex Maiden na Região de Botucatu-SP

JORGE MITIYO MAEDA

Aprovada em: 11/08/1988

Comissão Julgadora

Prof. Dr. Paulo Yoshio Kageyama ESALQ/USP

Prof. Dr. Mārio Ferreira ESALQ/USP

Prof. Dr. José Djałr Vendramin ESALQ/USP

Prof. Dr. Evôneo Berti Filho ESALQ/USP

Prof. Dr. Fábio Poggiani ESALQ/USP

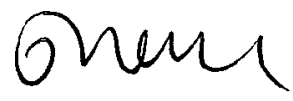

Prof. Dr. PAULO YOSHIO KAGEYAMA Orientador 
.iii.

Dedico

a Regina, Elisa

e Marcelo. 
A G R A D E C I M E N T O S

Os meus mais sinceros agradecimentos e em especial deferên cia:

- Ao Professor Paulo Yoshio Kageyama que orientou-me na rea lịzação deste trabalho;

- A DURAFLORA Silvicultura e Comércio, pela instalação e con dução da experimentação;

- Ao Professor Mário Tomazelo Filho, pelas fotografias e uso do laboratório;

- A Universidade Federal Rural do Rio de Janeiro - (UFRRJ) pe la oportunidade de realização do Curso de Pós-Graduação;

- Aos Professores Evôneo Berti Filho e Sinval Silveira Neto, da Escola Superior de Agricultura "Luiz de Queiroz" da Uni versidade de São Paulo - (ESALQ/USP), pela identificação dos insetos;

- A Companhia Vale do Rio Doce pelo uso do Sistema de Compu tação;

- Ao Centro de Processamento de Dados da UFRRJ, nas pessoas do Professor Jorge Paladino Corrêa de Lima e Técnico " Alan Cardeck, pelo processamento de dados;

- Ao Professor Ubirajara Contro Malavasi - UFRRJ, pela - cola boração;

- Aos Engenheiros Florestais Edmir Lopes Mora e Gilmar Berto loti enquanto Engenheiros da DURAFLORA Silvicultura e Comér cio;

- Ao Engenheiro Florestal Edson Mori do Instituto de Pesqui sas Florestais - (IPEF), pelas sugestões;

- Ass laboratoristas do Laboratório de Sementes Florestais da ESALQ/USP; e

- A todos que direta ou indiretamente contribuiram para que este trabalho fosse possivel de ser realizado. 


\section{RESUMO}

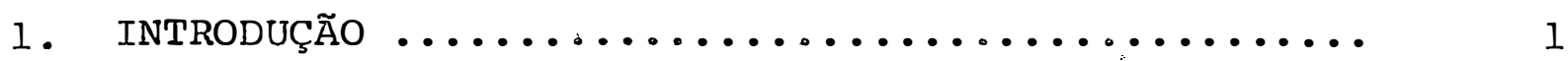

2. REVISÃO DE LITERATURA ..................... 4

2.1. Eucalyptus grandis: Ocorrència natural, im portância e melhoramento ............... 4

2.2. Sistema reprodutivo dos Eucalyptus ........ 6

2.3. Endogamia em espēcies florestais ........ Il

3. MATERIAIS E METODOS ........................ 15

3.1. Materiais ........................ 15

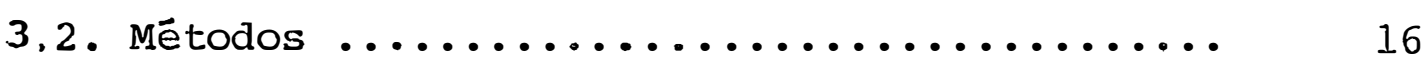

3.2.1. Fase I - Identificação dos clones do Pomar de Sementes heterozigotos para al binismo ................... 16

3.2.2. Fase II - Estudo do comportamento da entomo fauna da região das flores do Po

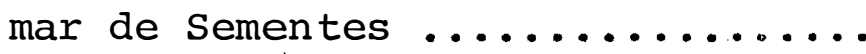

3.2.3. Fase III Estudo da importância dos insetos como polinizadores no Pomar de Se

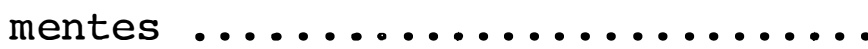

4. RESULTADOS E DISCUSSÃo .................... 38

4.1. Detecção de clones heterozigotos para albi nismo e estimação da taxa de autofecundação

4.1.1. Produção de plântulas albinas ........... 38

4.1.2. Estimação da taxa de auto-fecundação ...... 42 
4.2. Avaliação da Entomofauna do Pomar de Semen

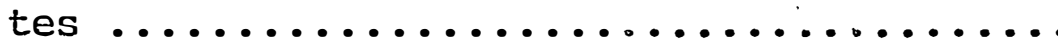

4.2.1. Quantificação dos insetos e cargas de pō

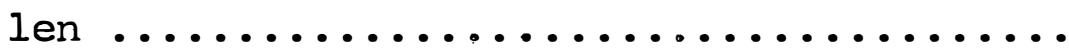

4.2.2. Comportamento dos insetos nos diferentes locais do Pomar de Sementes e períodos do

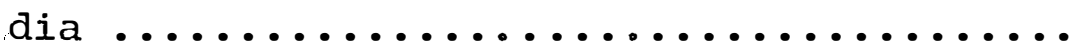

4.3. Resultados referentes à verificação dos in setos como polinizadores ............

4.3.1. Produção de sementes em ramos engaiolados.

4.3.2. Efeitos dos insetos na auto-fecundação no

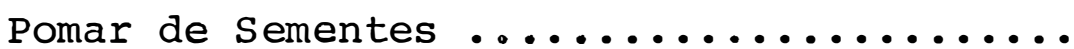

5. CONCLUSÕES ....................... 


\section{LISTA DE TABELAS}

NO

PĀGINA

01 Classificação de clones do Pomar de Sementes de E. grandis, segundo a capacidade de produção de plân

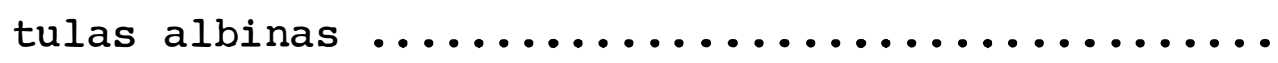

02 Médias gerais e percentuais de diferentes tipos de de plântulas para amostras de $0,25 \mathrm{~g}$ de sementes do Pomar de sementes de E. grandis ..............

03 Resultados da análise de sementes dos clones hete rozigotos para albinismo. Número de plântulas clo rofiladas e albinas em $0,25 \mathrm{~g}$ de sementes e estima tiva de porcentagem de auto-fecundação ino Pomar

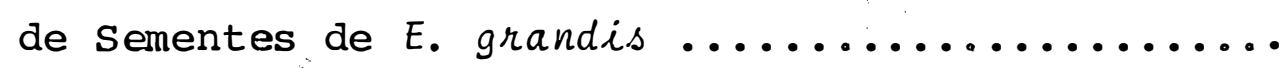

04 Relaçắo de insetos transportadores de pölen por ox dem decrescente de carga de pölen. Mêdias de 4 dí as de carga de pólen e frequência de insetos .....

05 Relação dos insetos mais importantes no Pomar de Sementes de E. grandis com suas respectivas médias de frequências e cargas de pólen transportados, em porcentagem ...........................

06 Tempo de permanência média dos insetos na mesma

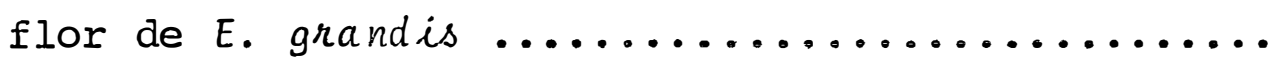

07 Frequência média de quatro dias de captura dos seis insetos mais importantes, nos períodos do dia

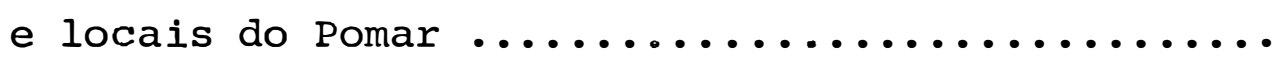

08 Médias de frequência de insetos por 'temperaturas médias de 4 dias dos períodos de captura, no Pomar

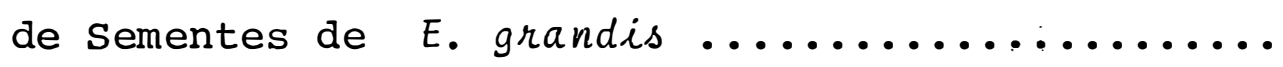


09 Valores de F para análise conjunta de médias de seis principais insetos nos dias de captura, perío dos do dia e locais do Pomar .................

10 Resultados de número de sementes e nümero de semen tes germinadas por quilograma, em diferentes trata mentos em ramos de enxertos heterozigotos para al binismo, em Pomar de sementes de E. grandis ......

11 Valores mëdios de auto-fecundação estimada por tra tamento em Pomar de Sementes de E. grandis .......

12 Quadro resumo para valores de $F$ da análise de vari ância para resultados dos tratamentos de engaiola mento de ramos de enxertos heterozigotos para albi nismo, em Pomar de Sementes Clonal de E. grandis.

13 Tabela de diferenças entre médias de : tratamentos pelo Teste de Duncan a nivel de 5\%, para resulta dos de engaiolamento de ramos de enxertos heterozí gotos para albinismo em Fomar de sementes Clonal de E. grandis ......................... 


\section{LISTA DE FIGURAS}

01 Esquema do Pomar de Sementes Clonal de E. grandis com a localização dos enxertos dos grupos por cap

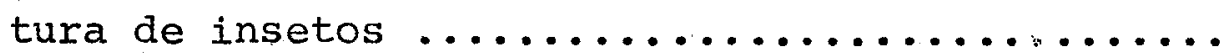

02 Grãos de pölen de E. grandis observados em Câmara de "Neubauer", para quantificação da carga de pó len em insetos .......................

03 Esquema do Pomar de Sementes de E. grandis com a localização dos clones heterozigotos para albinis mo e enxertos heterozigotos vizinhos mais próxí

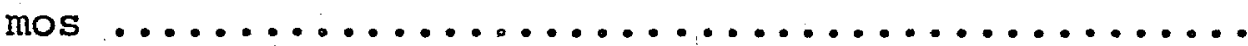

04 Ramos de enxerto. heterozigoto engaiolados com ramos de enxertos homozigotos para albinismo, jun tamente com insetos, em pomar de sementes de $E$.

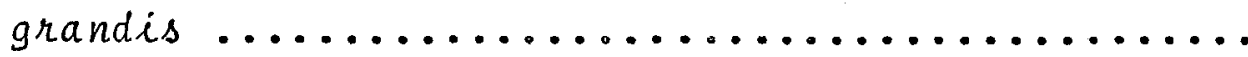

05 Enxerto heterozigoto para albinismo com todos tra tamentos de engaiolamento instalados, em Pomar de Sementes de E. grandis ...................

06 Plântulas albinas obtidas a partir de engaiolamen to de ramos de enxertos heterozigotos para albi

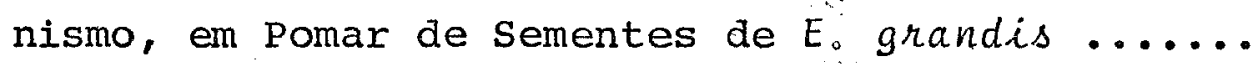
Frequência média de insetos e variação de temperatura no Pomar de Sementes de E. grandis, nos pe ríodos do dia.........................

08 Associação entre frequências mẻdias de insetos mais importantes no Pomar de Sementes de E. gran dis e suas respectivas cargas mëdias de pōlen ... 
INSECT' POLLINATION IN Eucalyptus grandis HILL eX MAIDEN CLONAL SEED ORCHARD AT BOTUCATU-SP.

Author: JORGE MITIYO MAEDA Adviser: Prof. Dr. PAULO YOSHIO KAGEYAMA

S U M M A R Y

An Eucalyptus grandis Hill ex Maiden seed orchard lo cated in Botucatu-SP, established to improve vigour, stem form and resistance to stem canker was used to test the importance of in sects on pollination.

The experimental design was composed of three sta ges: a) heterozygotic clone identification for albinism; b) in sect populations survey present at flowering; c) quantification of insect role on $E$. grandis pollination.

The number of heterozygotes for albinism were 6 out of 84 clones and 21 out of 217 grafts. Based on the frequency of albinitic seedlings the rate of natural selfing at : the seed 
Orchard was estimated to be $5.57 \%$, which was considered to be low and, therefore, an indicator that genetic variability is being efficiently maintained by insect pollination.

The sistematic survey of insect populations showed 118 species captured by the end of the 4 th day. Pollen load trans port quantified by the "Neubauer" chamber, indentifyed 26 insect species as being $E$. grandis pollinators; among these, only 6 species were defined as important based on their frequencies and pollen loads. Apis mellifera contributed with $36.02 \%$ of the total number of insects at the seed orchard and was responsable for $83.09 \%$ of the total polien transported. Astylus variegatus was the second most important insect with $32.30 \%$ and $5.74 \%$ of frequency and pollen load respectively.

Analysis of frequency data indicated a significant interaction (at $\mathcal{C}=0.05$ ) between periods and days of capture. Furthermore there were no differences: among places of insect sampling within the seed orchard, the interaction between places of insect sampling and periods of capture and the interaction between places of insect sampling and days.

Therefore, it was concluded that pollination was uniform within the seed orchard in all periods and days. : There was no significance between frequency and temperature of $:$ the periods for insect capture; the same trend was observed between insect frequency and pollen loads which had a linear correlation coefficient of 0.76 . 
To test the role of insect pollination for $E$. gran dis 7 treatments involving 5 heterozygotic grafts associated with A. mellifera and A. variegatus or both were established to ensure selfing or cross pollination on exclusion cages with or without homozygotic clones. Seed of the above treatments showed that $A$. variegatus presented higler selfing rate $(20.16 \%)$, when homozy gotic clones were absent white the no caging treatment showed a lower selfing rate $(1.24 \%)$.

The lowest rate of selfing $(0.8 \%)$ was obtained with caging of A. mellifera and homozygotic grafts. This value indi cates that $A$. mellifera was the most important insect for $E$. grandis seed orchard in respect to frequency, pollen load trans ported and random visiting among flowers and grafts. 
POLINIZAÇÃO EITTOMÖFILA EM POMAR DE SEMENTES CLIONAL DE Eucalyptus grandis Hill ex Maiden na Região de Botucatu-SP

Autor: JORGE MITIYO MAEDA. Orientador;Prof. Dr. PAULO YOSHIO KAGEYAMA

RESUMO

O Pomar de Sementes de Eucalytpus grandis Hill ex Maiden instalado na ārea da DURAFLORA Silvicultura e comērcio no Município de Botucatu-SP, e objeto deste estudo foi implantado pa ra fins de melhoramento para vigor, forma do tronco e contra o fungo causador do câncro em caule de Eucalyptus.

O experimento foi instalado em três fases distin tas: a) - Identificação dos clones do E. grandis heterozigotos para albinismo; b) - Análise da entomofauna presente nas flores do Pomar de Sementes de E. grandis; c) - Avaliação dos ' insetos como agentes polinizadores de $E$. grandis. 
Na primeira fase, foram analisados 84 clones e 217 enxertos, que revelou a existência de 6 clones e 21 enxertos hete rozigotos para albinismo. A partir da frequência de plântulas al binas desses enxertos heterozigotos, estimou-se em 5,57\% a taxa de auto-fecundação no Pomar de Sementes, que foi considerada bai xa e que, portanto, a variabilidade genética do Pomar de Sementes vem sendo mantida pela eficiência dos insetos polinizadores.

Na fase de avaliação da entomofauna da região das flores do $E$. grandis no Pomar de Sementes, foram capturados inse tos sistematicamente e, no final do 40 dia foi capturado um total de $1: 8$ espécies de insetos que tiveram suas cargas de pólen em transporte quantificados através do uso da câmara dé "Neubaueŕ".

Do total de 118 espécies de insetos analisados, 26 espēcies apresentaram transporte de pólen sendo então denominados como insetos polinizadores do $E$. grandis. Dentre estes, somente 6 espécies foram tidas como mais importantes pelas frequências : e cargas de pólen; dessas 6 espēcies a Apis mellifera representou $36,02 \%$ do número de insetos no Pomar de Sementes, com 83,09\% do total de pölen transportado. O Astylus variegatus foi considera do como o segundo inseto mais importante do Pomar de Sementes, com $32,30 \%$ e $5,74 \%$ de frequência e carga de pólen, respectivamente.

A ànálise de variância dos dados de frequência de insetos demonstrou que existem diferenças a nível de 5\% para pe ríodos no dia, dias de captura e para interação entre periodos e 
dias. Não foram detectadas diferenças significativas para os lo cais no Pomar de Sementes, para interação entre locais e períodos e para interação entre locais e dias, o que levou a concluir que a polinização era uniforme em todo o Po'mar de Sementes em todos os dias e períodos.

Os estudos demonstraram que não houve correlação significativa entre frequência de insetos e temperaturas dos pe Iiodos dos dias, o mesmo não acontecendo entre frequência de inse tos e cargas de pólen que apresentou valor de coeficiente de cor relação linear de 0,76 , significativo a nível de 1 웅 pelo teste $t$.

Na verificação da importância dos insetos como poli nizadores, foram montados 7 tratamentos em 5 ensertos de clones heterozigotos para albinismo, associados aos insetos A. mellifera e A. variegatus. Os tratamentos em enxertos de clones heterozigo tos consistiram em realizar polinização cruzada e auto-fecundação restritas somente aos insetos estudados e que foram engaiolados com ramos dos enxertos de clones heterozigotos, com e sem ramos de enxertos de clones homozigotos dominantes.

Os dados das sementes dos tratamentos de engaiola mento de ramos de clones heterozigotos revelaram que o A. varie gatus, quando na ausência de ramos de enxertos de cloneş homozigo tos, apresentou a maior taxa de auto-fecundação, com valor de $20,16 \%$ de auto-fecundação; enquanto o tratamento de ramos livres apresentou a menor taxa de auto-fecundação, com valor de 1,24\%. 
-xvi.

o menor valor da taxa de auto-fecundação com engaio lamento de insetos foi obtido com a A. mellifera e ramos de enxer tos de clones homozigotos, que foi de 0,8\%. Esses valores refor çaram a A. mellifera como o inseto mais importante do Pomar de Se mentes de E. grandis, quando observada a sua frequência, carga de pólen transportada e movimentação entre flores e enxertos. 
1. INTRODUÇÃO

As espēcies dos gêneros Eucalyptus e Pinus, com ên fase do primeiro, constituem a grande maioria das espëcies cultị vadas pelo setor florestal no Brasil.

Das inümeras espēcies do gênero Eucalyptus, a espécie Ecalytptus grandis Hill ex Maiden pode ser citada como uma das mais importantes pelas suas elevadas características silvicultu rais, da madeira e a própria resposta aos métodos de melhoramento empregados.

Os métodos de melhoramento empregados nas espécies florestais são baseados em se selecionar populações, atravēs de testes com espécies e procedências, com a posterior seleção de in divĩduos com melhores performances para constituírem as áreas de produção de sementes ou pomares de sementes. Esses métodos,em re sumo, consistem na exploração da variabilidade natural, com inten sidades de seleção variando para cada caso, na produção de semen tes melhoradas. 
Os dados de consumo de sementes demonstram que no a no de 1977, houve consumo de $4.608 \mathrm{~kg}$ de sementes de E. grandis para um total de $7.114,50 \mathrm{~kg}$ de sementes de Eycalyptus. Destas se mentes, somente cerca de $30 \%$ eram produzidas no Brasil, sendo a sua maioria em Pomares de sementes Clonais e Area de Produção de Sementes.

As espëcies do gênero Eucalyptus são citadas con $\underline{\underline{s}}$ tantemente por diversos pesquisadores como sendo :.. de reprodução. sexuada alogâmica e de polinização entomófila, na maioria dos ca sos. A manutenção da variabilidade natural dessas espēcies $\because$ em suas áreas de ocorrências naturais é garantida pelo cruzamento en tre diferentes indivíduos das populações, resultado do eficiente trabalho dos agentes polinizadores, em"especial dos insetos.

No Brasil, a situação das espēcies de Eucalyptus, despertam preocupações pelo fato delas serem introduzidas com to tal ignorância aos agentes polinizadores naturais e pela falta de conhecimento da adaptação dos eucaliptös aos insetos para polini zação aqui jā existentes, quando na introdução das mesmas.

Em termos de observações prāticas, tem-se verificado que as populações de eucaliptos no Brasil, na época do floresci mento, são visitadas por uma grande quantidade de insetos, aparen temente realizando trabalho de polinização, uma vez que hã a pro dução de sementes viāveis.

Portanto, a proliferação de Pomares de Sementes clo nais, instalados a partir de intensidades de seleção cada vez 
maiores e o desconhecimento da eficiência dos agentes poliniza dores:em condições brasileiras, despertam preocupações pela possi bilidade da produção de sementes com taxa de endogamia a níveis danosos e, consequentemente, a perảa de vigor nas gerações futü ras.

Com vistas a responder as questões citadas, o presen te trabalho teve por objetivos:

a) - Determinar os insetos visitantes das flores de E. grandis e sua importância como polinizadores;

b) - Estudar o efeito dos insetos polinizadores na produção de se mentes da espēcie. 
2. REVISÃO DE LITERATURA

2.1. Eucalyptus grandis: ocorrência natural, importância, e melhoramento.

- Eucalyptus grandis ocorre naturalmente no continen te australiano entre as latitudes $17^{\circ} \mathrm{S}$ a $33^{\circ} \mathrm{S}$ (ELDRIGE, 1976). Se gundo HALL et alii (1970), essas latitudes compreendem as locali dades do litoral de Newcastle em New South Wales e limita a dis tribuição perto de Mackay e Atherton ao norte de Queensland.

Essa distribuição, segundo BURGES (1983), se dá de forma quase contínua entre Rockhampton em Queensland e Newcastle em New South Wales, entre as latitudes de $23^{\circ} \mathrm{S}$ e $32^{\circ} 52^{\prime} \mathrm{s}$. Nas re giões de Carnavon, Mackay e Atherton em Queensland, a distribui ção è descontínua.

o E. grandis é encontrado desta forma,principalmente no litoral, quase ao nível do mar, porém, chegando até a $1.100 \mathrm{~m}$ de altitude em Atherton, em clima sub-tropical na maioria das regiões e com alta umidade relativa do ar em todos os locais durante todo 
- ano e com verão chuvoso, com precipitação na ordem de $1.500 \mathrm{~mm}$ por ano (BURGESS 1983).

Segundo KAGEYAMA (1980), dentre as espēcies de :Euca lyptus mais utilizadas no Brasil destacam-se: E.grandis Hill ex Maiden E.saligna Smith e E. urophylla Blake, com a madeira dessas espécies destinando-se à indústria de papel e celulose, chapas dü ras e para a produção de carvão.

O E. grandis pelas suas características silvicultu rais e tecnológicas favoráveis, aliadas ao seu bom comportamento em amplas condições ecológicas, vem tomando cada. vez mais impor tância tanto no Brasil como em outros países com clima tropical, merecendo cada vez mais importância em termos de melhoramento ge nētico (KAGEYAMA, 1980).

Com relação à escolha de melhores procedèncias de E. grandis a mais utilizada, de acordo com MORAES (1987) è a de Coff's Harbour, que propiciou a implantação de extensas āreas nos anos de 69 e 70, nas regiões de Mogi-Guaçu e Salto no Estado de São Paulo, sendo que estas populaŗões vêm sendo utilizadas como bases para programas de melhoramento, atravës de seleção intrapo pulacional.

Na seleção intrapopulacional, KAGEYAMA (1980) cita que a seleção fenotípica individual dentro de populações base ade quadas e sua utilização para a produção de sementes melhoradas $\underline{\text { a }}$ travēs dos "Pomares de sementes" tanto por clones como por mu das, contitui-se num dos métodos mais correntes no melhoramento florestal. 
2.2. Sistema reprodutivo dos Eucalyptus.

o sistema reprodutivo de um organismo è a probabi lidade de diferentes tipos de gametas chegarem a formar juntos os zigotos, e que pode ser alterado por mecanismosfisiológicos, flo rais e genéticos (ELDRIDGE, 1976).

A inflorescência do $E$. grandis è do tipo umbelas axi lares em pedúnculos achatados, cada uma com 7 a 12 flores, com pe dicelos comumente curtos ou ausentes e ocasionalmente longos. Os botões florais são periformes com opērculo de ponta obtusa de $1,0 \times 0,5 \mathrm{~cm}$, revestido de cêra branca (HILL et alii, 1970).

A característica mais importante das : flores dos Eucalyptus è a presença do opérculo, que funciona como uma capa protetora que recobre os órgãos reprodutivos em fase de pré-ante se floral (PRYOR, 1976).

Ainda segundo PRYOR (1976) e FREE (1970), o opérculo em muitas espécies de eucalipto é uma combinação de duas capas se melhantes sobrepostas, que desempenham funções de pētalas e sēpa las, respectivamente, de uma flor țetrâmera, que na maioria dos Eucalyptus apresentam grande nümero de estames para um ūnico es tỉgma.

o ovário das flores dos Eucalyptus possui de três a seis células, cada uma com numerosos óvulos. O estígma torna-se receptivo somente 4 a 7 dias após a queda do segundo opérculo e conseqüentemente, quando o pólen da própria flor já foi totalmente 
disperso. Desta forma, a totalidade das espẹcies dos Eucalyptus apresenta flores bisexuais com androceu e gineceu férteis na mes ma flor, porēm, com a ocorrência da protandria (JACOBS, :1979, e FREE, 1970).

HODGSON (1976) descreve que a maioria do florescimen to do E. grandis ocorre entre fevereiro e junho, porém è extrema mente variāvel com a altitude e algumas floradas extras ocorrem fora do periodo normal. Os botões:florais atingem a ântese 4 meses após a diferenciação da gema axilar.

A flor dos Eucalyptus, segundo a classificação de FAEGRI e van der PIJL (1971), apresenta sindrome floral para meli tofilia, uma vez que as mesmas são do tipo pincel, de cor amarela que atraem abelhas e tambëm borboletas e pássaros.

No Brasil, segurido AMARAL (1960), os principais inse tos polinizadores de espécies de polinização entomófila são a Apis mellifera L., introduzida da Europa, e dentre as espécies na tivas, o autor considera que as mais importantes pertencem aos gê neros Megachiline, Bombus, Xylocopa dentre outros.

Segundo ASHTON (1975) e HILLS \& BROWN (1978), pelo fato do pólen de Eucalyptus não ser favorāvel a dispersão pelo vento, a polinização è basicamente entomófila: o nēctar produzí do pelas flores do gênero é um atrativo para visitação de muitos insetos, pāssaros e pequenos mamíferos que são tambēm importantes na polinização dàs espēcies em habitat natural. 
Os Eucalyptus são tidos como de flores protândricas e a maioria da polinização é efetuada por insetos (KRUG e ALVES, 1949 e PRYOR, 1951). Contudo, os pāssaros tambēm são responsā veis em parte pela polinização dessas espécies (CHRISTENSEN 1971).

De acordo com PRYOR \& BODEN (1967), as flores dos eucaliptos são visitadas por uma grande variedade de insetos na Austrália. Dentre eles estão identificados 11 espécies de Coleop tera, o mesmo número de Hymenoptera e Lepidoptera e também por He miptera e Diptera.

As ordens dos insetos polinizadores de Eucalyptus que merecem destaque, segundo MORA et alii (1981), são Coleoptera (besouros): Lepidoptera (borboletas e mariposas); Diptera (mos cas, mosquito pólvora, borrachudos, etc) e Hymenoptera (vespas, abelhas e outras!.

BERTI FILHO (1981) fazendo um levantamento da ento mofauna presente nas populações de Eucalyptus no Brasil, encontrou um total de 10 ordens, 75 familias e 388 espécies de insetos associados a este gênero. A entomofauna da região das flores e frutos dos eucaliptos é constituỉda por 6 ordens, 17 familias e 34 espécies de insetos, sendo que a familia Vespidae (Hymenoptera) apresentou. Il espécies e a família Apidae apresentou as espé cies Apis mellifera mellifera LINNE, Bombus sp.; Oxytrigona tataia tataia F. SIMITH. e Xylocopa sp.

Os estudos de pasto apícola realizados por SANTOS (1962) demonstraram que, dos principais tipos de pólen coletado 
por abelhas A. mellifera na região de Piracicaba/são Paulo maior constância verificada foi para os pólens de Eucalyptus spp., representando uma média de $46,5 \%$ do peso total.

$$
\text { STANLEY \& LINSKENS (1974) e AMARAL (1951) afirmam }
$$

que as abelhas são totalmente adaptadas ao trabalho de coleta e transporte de póléen, uma vez que seu corpo é coberto por finos pê los onde o pólen adere-se quando na visitação às flores. o segun do autor sugere que os pêlos, principalmente da parte ventral dos insetos, ë que são os responsáveis pela polinização efetuada pe los insetos.

ASHTON (1975) verificou que na Austrālia o E.regnans é visitado no florescimento por abelhas A. mellifera e híbridos de A. Lusitanica, Leioproctus blavomaculatus Cockerell e Callomel litita picta (Smith); Eristalis sp; Anastellorhina stygia Fab.; moscas (Thinnidade), besouros (Mordella sp); formigas (Myrmecia nigracineta Smith e Iridonyrmex sp) e borboletas e mariposas (A grotis infusa Boisd). Caradrina cryphae Turnee e oreixenica latho mella Herceus.

Nos eucaliptos, o häbito reprodutivo predominante é - sexuado, com exceção para três espēcies que apresentam a propa gação vegetativa natural por rizoma (ELDRIDGE, 1976).

Segundo PRYOR (1976) e FRANKEL \& GALUN (1977), os eu caliptos são espēcies alogâmicas que possuem os insetos como prin cipais agentes'vetores de pólen entre ärvores. 
HODGSON (1976) acentua que nos eucaliptos há a prẹ dominância da bisexualidade, com ocorrência da protandria em algu mas espécies. Ainda segundo o autor, como a protandria é uma for ma de auto-incompatibilidade, esta ocorrência vem reforçar a pre dominância da alogamia no gênero Eucalyptus.

No entanto, HODGSON (1976) observa que se a viabili dade do pólen for considerada como o critērio mais importante na determinação do modo de fertilização, a auto-polinização passa a ier predominante em eucaliptos em condições onde não haja alta probabilidade do pólen de alguma ärwore alcançar o estígma de uma outra com floração abundante. 


\subsection{Endogamia em Espëcies Florestais}

SEgundo FALCONER (1960) e METTLER e GREGG (1973), en dogamia é o acasaíamento de indivíduos que estão aparentados en tre si por descendência, e que depende do tamanho da população.os tipos mais comuns desses acasalamentos são: auto-fecundação, aca salamento entre irmãos-germanos, acasalamento entre meios-irmãos, retrocruzamentos repetidos e auto-fecundação parcial.

Os coeficientes de endogamia para esses casos de aca salamento endogâmicos, para a primeira gèração são: 0,$500 ; 0,250$; 0,125 e 0,250, respectivamente para progênies de anto-fecundação, meios-irmãos, irmãos-germanos e retrocruzamentos repetidos. Para gerações de auto-fecundação parcial, depende da taxa de auto-fe cundação na população e,a maioria dos efeitos ocorrem na primeira geração (FALCONER, 1960 e VAN WYK, 1980).

Em relação às causas da ocorrência da endogamia, KA GEYAMA (1981) argumenta que o aumento ao máximo da intensidade de seleção, visando o maior ganho genético possível por geração, desconsiderando-se a redução excessiva do tamanho de uma população, - acasalamento entre indivíduos aparentados, de ocorrência não intensional ao melhorista florestal e as condições ideais para prodụção māxima de sementes em Pomar de Sementes, são as causas mais comuns que levam os individuos à endogamia a vārios níveis.

o florescimento irregular e a deficiência na polini zação também são citạaos por MORA et alii (1980) como fatores que provocam a endogamia. 
GRANT (1950) observa que as abelhas permanecem du rante longo tempo em um mesmo ramo florido, causando assim um grande nümero de autopolinização. Esta opinião, no entanto, ' é contestada por PACHECo (1982) que utilizando a técnica de ${ }^{32} \mathrm{P}$ (radiativo) em marcação de ramos de ārvores de E. saligna, deter minou que em um ūnico vôo as abelhas adquiriram pólen das ārvo rəs marcadas e as transferiram para vārias outras, realizando po Iinização cruzada.

o acasalamento entre indivíduos aparentados, princi palmente entre irmãos germanos e meío-irmãos, è de fäcil ocorrên cia em espécies florestais, já que grandes áreas podem ser plan tadas com pequenas quantidades de sementes. Essas sementes podem provir de pequeno nümero de ärvores ou mesmo de uma ünica ärvore, implicando em cruzamentos endogâmicos (KAGEYAMA, 1981).

HODGS়ON (1976) considera que a auto-fecundação ocor re em ārvores isoladas de eucaliptos, uma vez que têm sido obti das sementes viáveis nestas. Portanto, a capacidade para auto-fe cundação, no caso de falha de cruzamentos, pode ser uma vantagem na capacidade de sobrevivência dessas espécies.

A auto-polinização tem sido verificada como possível para a maioria das espēcies de Eucalyptus, segundo ELDRIDGE(1976). Porèm, o autor acentua que, como a autopolinização não ocorre em todas espēcies do gênero, não se constitui no hābito reproduti vo comum dos eucaliptos. Desta forma, o autor conclui que a auto polinização é um recurso da planta para a ineficiência do agente 
polinizador e quando hā problemas na estrutura genētica das popu lações.

A detecção da ocorrência de auto-fertilização nas es pécies florestais tem sido feita a partir de estudos de avaliação de progênies, com genes marcadores lalbinismos, cor de cotilédo nes, nanismo, etc.), atravēs da frequência de óvulos abortados e, mais recentemente através de isoenzimas (KAGEYAMA,1981). o albi nismo também foi utilizado como instrumento para evidenciar a ocorrência de autopolinização por ANDRADE (1960) e VAN WYK(1980), dentre outros.

Como efeitos da ocorrência da endogamia VENKATESH \& SHARMA (1974), estudando plântulas originárias de polinização a berta em E. tereticarnis S.M. Smith e E.camaldulensis Dehr, detec taram a ocorrência dos seguintes tipos de anomalias: plântulas gê meas; plântulas anormais em vạrias características; plântulas multicotiledonadas; plântulas albinas ou deficientes em clorofi la. As plântulas albinas e deficientes em clorofila que totaliza ram $0,18 \%$ e $21,19 \%$, respectivamente, do total das plântulas germi nadas, morreram ao fim de poucos dias após a germinação por exaus tão das reservas cotiledonais.

Segundo ELDRIDGE (1976) e JACOBS (1979), o resultado da endogamia é a depressão endogâmica; que se expressa no baixo crescimento das mudas no campo e na baixa viabilidade das semen tes. O retardamento no crescimento varia pouco em E. regnans $F$. Muell e E. camaldulensis e é considerāvel em E. grandis. 
HODSON (1976), analisando os clones de E. grandis em um Pomar de Sementes, estimou a redução no crescimento de plantas obtidas em auto-fecundação, em idades de 11 a 18 méses, em torno de 8 a $49 \%$, quando comparadas com plantas de cruzamen tos.

KAGEYAMA (1981) e ELDRIDGE (1976) citam vários ca sos que em se utilizaram genes marcadores para estudar a propor ção de sementes resultantes de autofertilização. Assuminảo que cada gene marcador è a expressão de un ūnico gene recessivo, e ignorando a frequência do gene em ārvores vizinhas, as estimati vas encontradas foram: $23 \%$ em 9 ārvores de E. alba Reinw ex Blu; $100 \%$ em 1 árvore de $E$. regnans $F$. Muell e 10 a $38 \% \mathrm{em} \mathrm{dí}$ versas árvores de $E$. grandis.

Ao analisar as sementes de nove matrizes de $E$.alba, ANDRADE (1960) observou a presença média de 5,7\% de indivíduos albinos em um total de 788 indivíduos; o que leva a estimar que a auto-fecundação no caso foi de $22,8 \%$

VENKATESH \& VARKSHASYA (1978) compararam os resulta dos entre híbridos de E. camaldulensis com E. tereticornis, pro gênies de auto-fecundação e progênies de meios-irmãos, determi nando que as diferenças entre essas três progênies não è apenas sustentada como também aumenta com a idade, tanto para altura de plantas como para diâmetro do tronco, com nitida superioridade para os híbridos. 


\section{MATERIAIS E METODOS}

3.1. Materiais

o local de experimentação constituiu-se de um Pomar de Sementes Clonal de Eucalyptus grandis Hill ex Maiden, situado no municipio de Botucatu/são paulo, a uma latitude de $22^{\circ} 52^{\prime} \mathrm{s}$ e longitude de $48^{\circ} 40^{\prime} \mathrm{W}$, de propriedade da DURAFLORA-Silvicultura e Comércio S.A., com 2 anos de idade e 2,54 ha de ārea, com espaça mento de $5,0 \times 2,5 \mathrm{~m}$ entre linhas e entre plantas, respectivamen te. o pomar foi formado a partir de clones selecionados para vi gor, forma do tronco e contra o câncro, oriundo de Coff's Harbour -Austrālia.

Segundo o mapa climatológico do Brasil, de acordo COM BRASIL-MINISTERIO DA AGRICULTURA (1969), com base no sistema de Kobper, o clima da região é do tipo Cwa - clima temperado bran do com inverno seco e verão quente, em que a temperatura do mês mais quente ultrapassa a $36^{\circ} \mathrm{C}$ e a mïnima do mês mais frio è em torno de $0^{\circ} \mathrm{C}$, com média de temperatura anual entre 18 a $20^{\circ} \mathrm{C}$. A 
precipitação total anual é de $1250 \mathrm{~mm}$, predominando nos meses mais quentes.

\subsection{Métodos}

O trabalho foi conduzido no campo e em laboratório, em três fases distintas e na seqüência:

Fase I - Identificação dos clones do Pomar de Sementes heterozî gotas para albinismo;

Fase II - Estudo do comportamento da entomofauna presente na região das flores dos enxertos;

Fase III - Estudo da eficiência dos insetos como polinizadores dos enxertos do Pomar de Sementes.

3.2.1. Fase I - Identificação dos clones do Pomar de Sementes heterozigotos para albinismo.

A identificação dos clones heterozigotos para albi nismo, teve início em janeiro de 1982, com o teste de germinação das sementes individualizadas por enxerto.

Para tanto, todos os frutos dos 84 clones e 217 en xertos foram colhidos individualmente. Os frutos colhidos des sa forma foram secos naturalmente ao sol e tiveram suas sementes extraỉdas, mantendo-se sempre a sua individualidade, sendo poste riormente enviadas ao Laboratório de Sementes do Departamento de Ciências Florestais da Escola Superior de Agricultura "Luiz 
de Queiroz" da Universidade de São Paulo, em Piracicaba - São Paulo, devidamente identificadas.

Foram utilizadas duas (2) amostras de trabalho de 0,25 g cada, das sementes obtidas a partir da homogeneização dos lotes, em divisor de solo tipo Dinamarquês, com pesos aferidos em balança analỉtica "Sartorius" S $1220 \mathrm{~N}$.

A partir das amostras, em teste de germinação em germinador "Biomatic" a $25^{\circ} \mathrm{C}$ constante, "Gerbox", substrato de papel e contagem aos 79 e 140 dias, foram identificados os clones heterozigotos para albinismo, atravēs das progênies com indivĩduos albinos.

Na deteç̧ão de clones heterozigotos para albinis mo, como não houve propriamente uma experimentação, os dados obtidos na germinação das sementes não foram submetidos a nenhuma análise estatỉstica. Porēm, os dados dos clones hete rozigotos foram importantes na estimação da taxa de auto-fecun dação média do Pomar de Sementes na geração estudada.

Para a estimação da auto-fecundação do Pomar de Sementes foram utilizados somente valores referentes aos clo nes heterozigotos para albinismo que, a partir dos valores mé dios de porcentagem de plântulas albinas produzidas, possibili taram a estimação da auto-fecundação no Pomar de Sementes, se gundo o princỉ fio da relação mendeliana, assumindo que a carac terística é monogênica. 
Como a média da porcentagem de plântulas albinas representa somente $25 \%$ do total de plântulas das auto-fecunda ções ocorridas, a estimativa da taxa de auto-fecundação média do Pomar de Sementes foi obtida multiplicando-se por 4 o valor percentual de plântulas albinas, considerando que a probabili lade de cruzamentos entre individuos heterozigotos è desprezi vel.

3.2.2. Fase II - Estudo do comportamento da entomofauna da região das flores do Pomar de Sementes.

Esta fase do trabalho, teve inỉcio em março de 1982, com a captura sistemática de insetos nos ramos floridos dos enxertos do Pomar de Sementes.

\section{a - Captura Sistemática dos Insetos:}

Devido a ausência de metodologia própria para avaliação nesses casos, foram demarcados 3 grupos com 10 enxer tos cada, com botões: florais abundantes,com a finalidade de se es tudar o comportamento da entomofauna presente nas flores dos enxertos, durante a época do florescimento.

Os três grupos de enxertos, denominados locais no Pomar de Sementes, foram localizados de forma a possibilitar os estudos referentes à penetração dos insetos da periferia pa ra o centro do pomar de Sementes, conforme Figura 01, na medi da em que todo o Pomar era circundado por vegetação nativa, que 
supõe-se ser o habitat natural dos insetos polinizadores.

Dentro de cada grupo, cada 2 enxertos próximos foram considerados uma repetição. Desta forma, cada grupo cons tou de 5 repetições.

Na captura dos insetos foram utilizadas rêdes en tomolögicas, onde cada repetição teve um perỉodo total de cap tura de 5 minutos, distribuídos em 6 períodos diários de captü ra. Cada dia de captura foi dividido em 6 periodos, a saber:

\begin{tabular}{cc}
\hline PERIODO DO DIA & INTERVALO - (HORAS DO DIA) \\
\hline 01 & $07: 00$ às $08: 00$ \\
02 & $08: 00$ às $10: 00$ \\
03 & $10: 00$ às $12: 00$ \\
04 & $12: 00$ às $14: 00$ \\
05 & $14: 00$ às $16: 00$ \\
06 & $16: 00$ às $18: 00$ \\
\hline
\end{tabular}




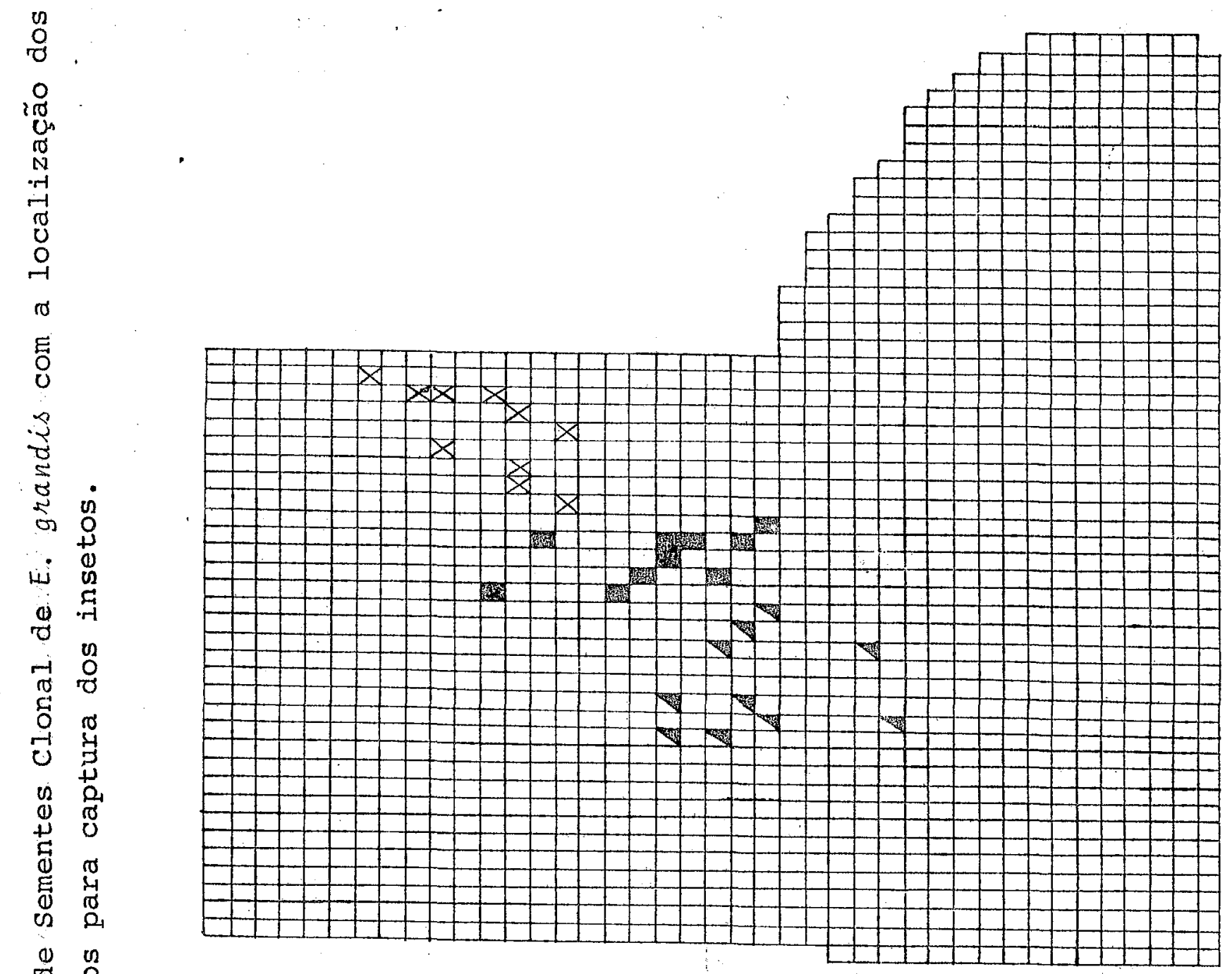

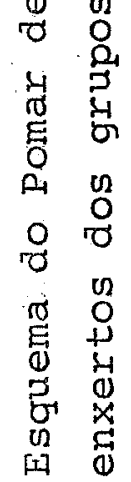

임
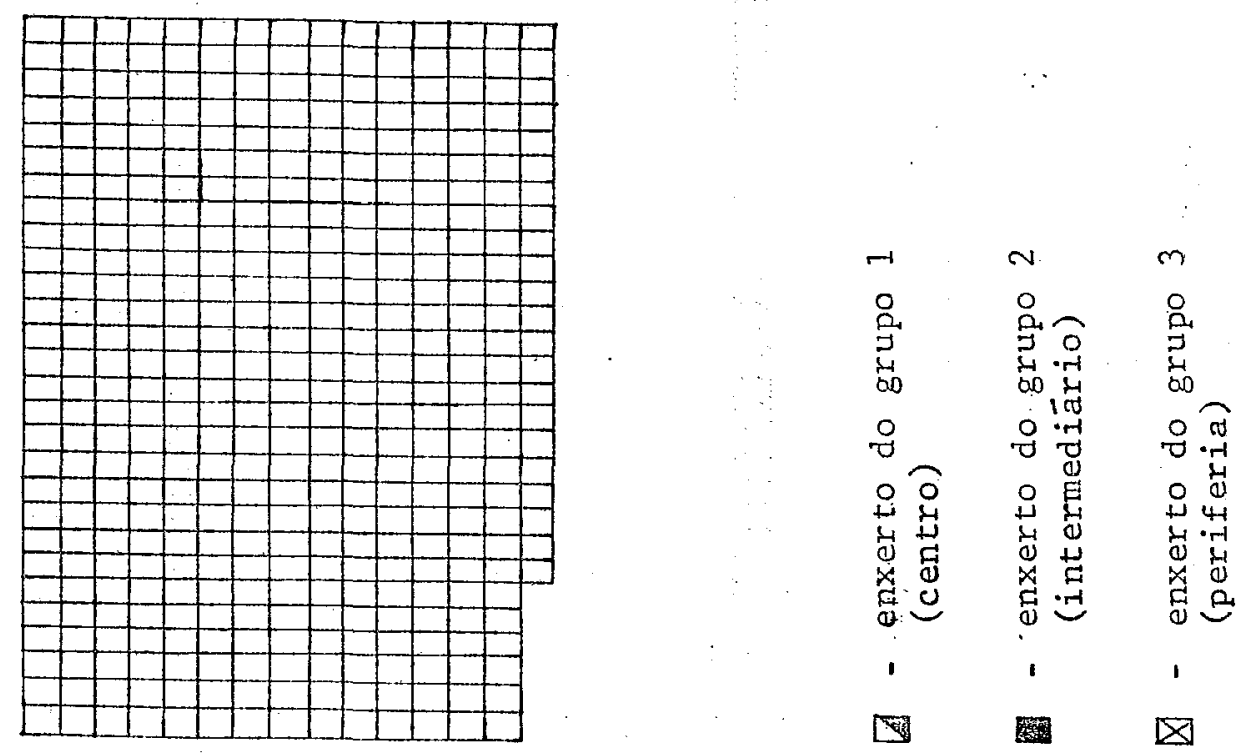

$\square$ 
Os insetos foram capturados sistematicamente durante todo o período de florescimento dos enxertos escolhidos, no perío do de 09/03/82 a 06/04/82, o que possibilitou a análise de flutua ções de populações de insetos visitantes.

Cada inseto capturado foi individualizado por espẹ cie, sendo identificado de acordo com o grupo, periodo e repetí ção correspondente, sendo portanto, no ato da captura, os insetos da mesma espécie e repetições mantidos agrupados no mesmo frasco de vidro, com capacidade de $15 \mathrm{ml}$ de volume.

Os insetos capturados foram conservados em älcool $70 \%$ em frasco de vidro e posteriormente enviados ao Laboratório de Sementes do Departamento de Ciências Florestais da ESALQ-SP, para estocagem em câmara sêca, com temperatura de $20^{\circ} \mathrm{C}$ e $75 \%$ de UR.

b - Quantificação da carga de pólen nos insetos:

Após o término do período de florescimento das árvo res, os insetos capturados foram submetidos à quantificação da carga de pólen.

Os frascos contendo insetos e álcool tiveram o volu me, após agitação manual para soltura de pölen aderido aos corpos dos insetos, corrigido para volume padrão de $10 \mathrm{ml}$ que constituiu no material para a quantificação de nümero de grãos de pólen em transporte no momento da captura. 
O mētodo empregado para quantificação da carga de pólen em insetos, foi descrito por TUITE (1969), que consis tiu em efetuar a contagem da amostrà em Câmara de "Neubauer", que até então não havia sido utilizada para esse fim, mas que se revelou perfeitamente empregável, dado ao tamanho reduzido do grão de pólen do E. grandis, conforme a Figura 02. 
.23 .

FIGURA 02 Grãos de pölen de $E$. grandis observados em Câmara de "Neubauer", na quantificação da carga de pólen em insetos. (aumento 10 X 38 e lente macro)

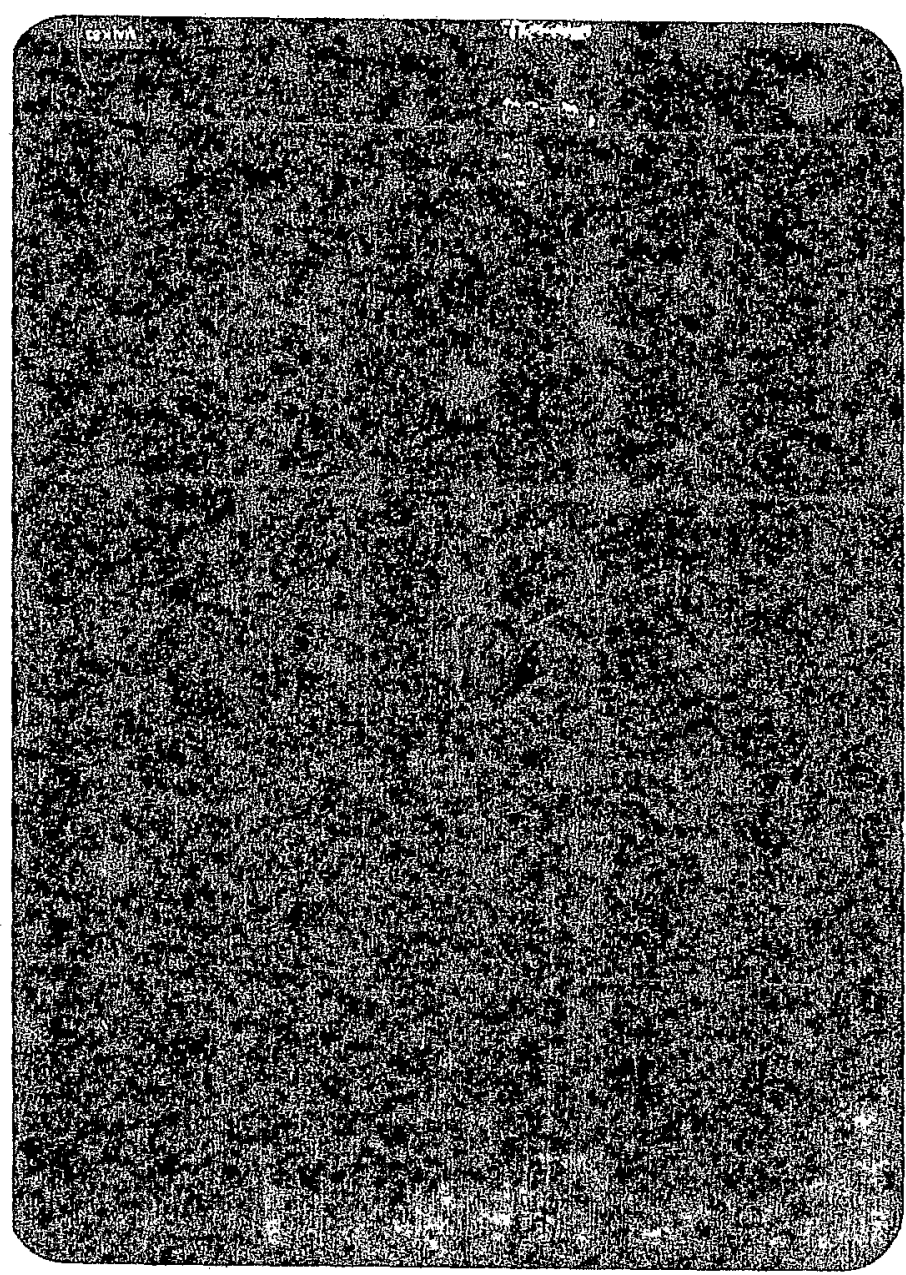


Como a Câmara de "Neubauer" apresenta 2 campos de contagem, e foram montadas 2 câmaras por frasco, cada fras co apresentou ao final um total de 4 repetições; nümero esse determinado previamente por apresentar o desvio padrão de 12,6\%, aceitável segundo o autor do mētodo.

O total de polén existente no frasco foi então calculado pela fórmula:

$$
N=\bar{x} \cdot v \cdot C
$$

onde: $\mathbb{N}=$ nümero total de pölen no frasco; $\overline{\mathrm{x}}=$ nümero médio de pölen dos quatro campos de contagem; $v$ = volu me de solução do frasco e $\mathrm{C}=$ constante 2.000 .

A partir do nümero total de pólen no frasco, cal culou-se o número médio de pólen por inseto do frasco, como se segue:

$$
\mathrm{P} / \mathrm{I}=\mathrm{N} / \mathrm{n}
$$

Onde: $\quad P / I=$ nümero médio de pólen por inseto; $\mathrm{N}=$ número total de pölen no frasco e $\mathrm{n}=$ número de insetos no frasco. 
c - Análise estatỉstica dos dados:

$\mathrm{Na}$ identificação dos insetos e capacidade de carga de pólen pelos insetos, os dados referentes à frequência de insetos nos diferentes dias, periodos e locais no Pomar de Sementes, foram analisados segundo delineamento de parcelas subdivididas, conforme esquema proposto por GOMES (1980).

Os dados referentes a frequência de insetos e cargas de pólen dispensaram transformações pelo fato de terem sido utilizados dados médios que, nestés casos, conduz à normalidade e conseqtientemente à redução dós erros.

\begin{tabular}{|c|c|c|c|c|c|c|}
\hline FV & GL & & & $S Q$ & $\mathrm{QM}$ & $\mathrm{F}$ \\
\hline Períodos nos dias & $(P-1)$ & & & $\mathrm{s}_{1}$ & $Q_{1}$ & \\
\hline Locais no pomar & $(I-I)$ & & & $\mathrm{s}_{2}$ & $\mathrm{Q}_{2}$ & \\
\hline Dias de captura & $(D-1)$ & & & $\mathrm{S}_{3}$ & $Q_{3}$ & \\
\hline Locais $\mathrm{X}$ periodos & $(L-1)$ & $(P-1)$ & & $\mathrm{S}_{4}$ & $\mathrm{Q}_{4}$ & \\
\hline Periodos $\mathrm{X}$ dias & $(P-1)$ & $(D-1)$ & & $\mathrm{S}_{5}$ & $Q_{5}$ & \\
\hline Locais X dias & $(L-1)$ & $(D-1)$ & & $\mathrm{s}_{6}$ & $\mathrm{Q}_{6}$ & \\
\hline Erro & $(P-1)$ & $(L-1)$ & $(D-1)$ & $\mathrm{s}_{7}$ & $Q_{7}$ & \\
\hline
\end{tabular}

$$
\begin{array}{rlrl}
F V & =\text { Fonte de Variação } & \text { GL }=\text { Grau de Liberdade } \\
\mathrm{SQ} & =\text { Soma dos Quadrádos } & \mathrm{QM}=\text { Quadrados Médios } \\
\mathrm{F} & =\text { Valor do Teste } \mathrm{F} & \\
\mathrm{P} & =\text { Número de Períodos nos Dias } & \\
\mathrm{L} & =\text { Número de Locais no Pomar } & \\
\mathrm{D} & =\text { Número de Dias de Captura de Insetos }
\end{array}
$$


Para se avaliar a existência de correlação entre frequências de insetos, cargas de pólen e perïodos dos dias (temperaturas em ${ }^{\circ} \mathrm{C}$ dos periodos dos dias), foram calculados os coeficientes de correlação Iinear.

3.2.3. Estudo da Importância dos Insetos como polinizado res no Pomar de Sementes.

A partir de abril de 1982, com base na determina ção de clones e enxertos heterozigotos para albinismo e a iden tificação dos componentes da entomofauna do Pomar de Sementes, tidos como prováveis polinizadores, estes tiveram as suas efici ências testadas.
a - Engaiolamento de ramos de enxertos heterozi gotos.

Para tanto, foram escolhidos 5 (cinco) enxertos em estágio inicial de ântese floral, onde foram instalados trata mentos de engaiolamento de ramos com os dois insetos de maio res frequências: Apis mellifera e Astglus variegatus, confor me a Figura 03 .

o engaiolamento de ramos teve por objetivo iso lar os ramos em teste, onde a produção de sementes pudesse ser atribuida somente aos insetos dos tratamentos correspondentes.

Os enxertos heterozigotos onde foram instalados os tratamentos foram: 


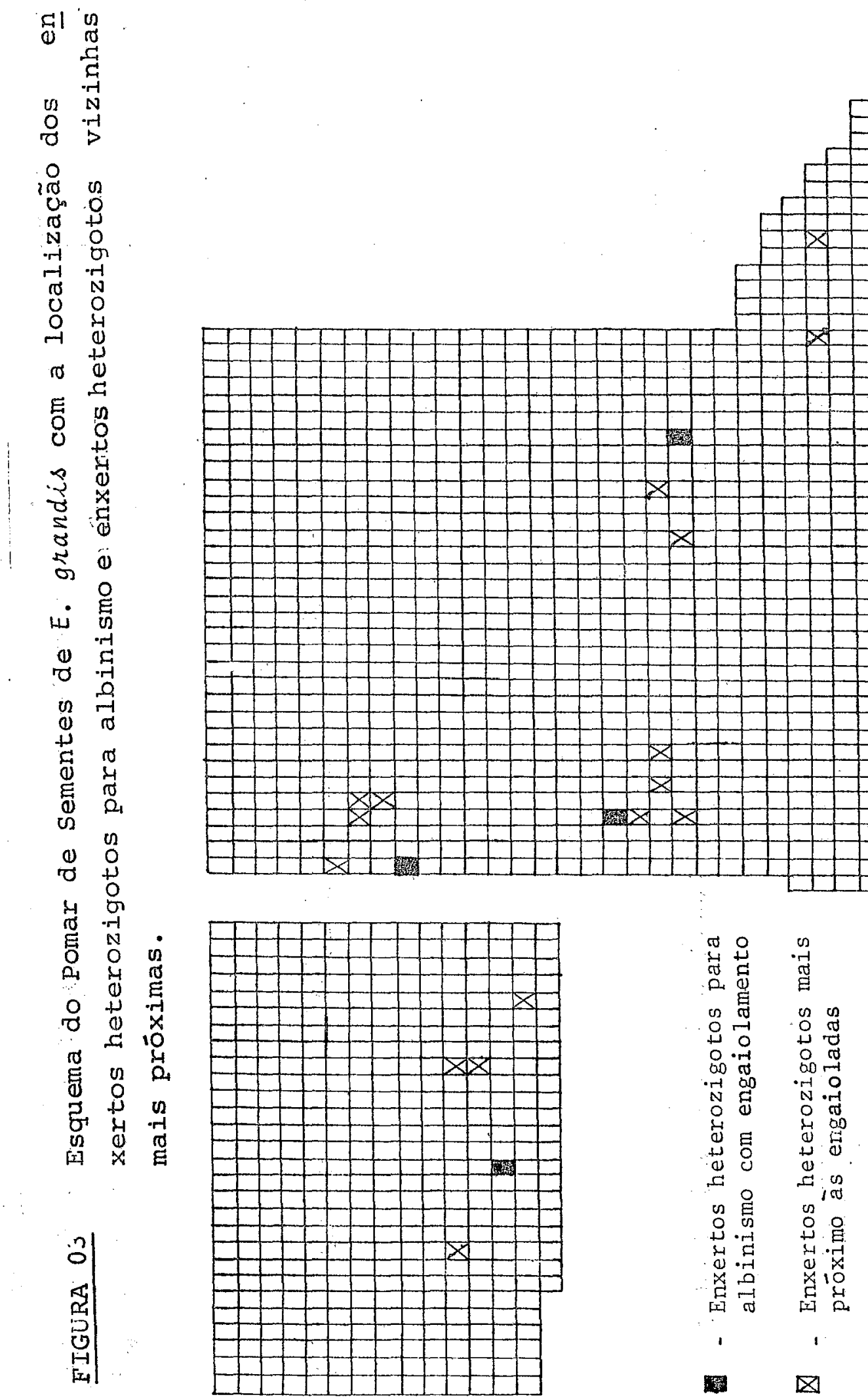




\begin{tabular}{lcc}
\hline Enxerto & Clone & Repetição \\
\hline BB 21 & 130 & A2 \\
BZ 37 & 149 & A1 \\
AB 9 & 149 & A4 \\
CS 13 & 166 & A5 \\
AE 18 & 166 & A3 \\
\hline
\end{tabular}

Em cađa ärvore, apōs eliminação das flores e man tendo somente os botões florais, foram instalados os seguintes tratamentos: 
TRATAMENTOS

01. Ramo do próprio enxerto heterozigoto, Apis mellifera e ramos de $\&$ enxertos homozigotos dominantes:

02. Ramo do próprio enxerto heterozigoto, Astylus varie gatus e ramos de 4 enxertos homozigotos;

03. Ramo do próprio enxerto heterozigoto, com inseto do do tratamento 01, sem ramos de enxertos homozigotos

04. Ramo do próprio enxertoheterozigoto, com inseto do tratamento 02, sem ramos de enxertos homozigotos:

05. Somente ramo de enxerto heterozigoto e sem insetos;

06. Ramo de enxerto heterozigoto, insetos dos tratamen tos 01 e 02 e ramos de 4 enxertos homozigotos;

07. Ramos livres de gaiola (testemunha).

Os tratamentos foram montados em gaiolas (Figuㅡ ras 04 e 05) semelhantes às utilizadas por ANDRADE (1960), dife renciando-se das mesmas na medida em que as utilizadas no tra balho possuiamas dimensões de 1,00 X 1,00 X 1,30 m de largura, profundidade e altura respectivamente, e com paredes de tela plástica com malha de $4,0 \mathrm{~mm}^{2}$, enquanto que as utilizadas pelo 
autor citado consistiam em cabanas com paredes de pano e que comportavam inclusive colméias de abelhas no seu interior.

No interior dessas gaiolas foram introduzidos ra mos dos enxertos em teste. Nos tratamentos 01,02 e 06 foram utilizados ramos de enxertos homozigotos próximos, com carga floral, preservados em baldes plásticos de 14 litros de capací dade de água, com o objetivo de se manter os ramos vivos, na medida em que esses se constituiram em fornecedores de pölen para o trabalho de polinização cruzada dos insetos tambëm en gaiclados.

Desta forma, nos tratamentos 01 e 02 estimou-se a eficiência de polinização da A. mellifera e do A. variegatus isoladamente e sem concorrência, enquanto no tratamento $06, \mathrm{ob}$ jetivou-se verificar a eficiência da polinização quando na con corrência entre ambos os insetos.

Nos tratamentos 03 e 04 , objetivou-se a verifica ção da capacidade de auto-fecundação dos clones e enxertos, quan do na presença de insetos isoladamente.

O tratamento 05 teve por finalidade testar a eficiência da gaiola entomológica em impedir a entrada .. de pólen e seus vetores ao seu interior. 
FIGURA 04 Ramos de enxerto heterozigoto engaiolados com ramos de enxertos homozigotos para albi nismo, juntamente com insetos, em Pomar de Sementes de E. grandis.

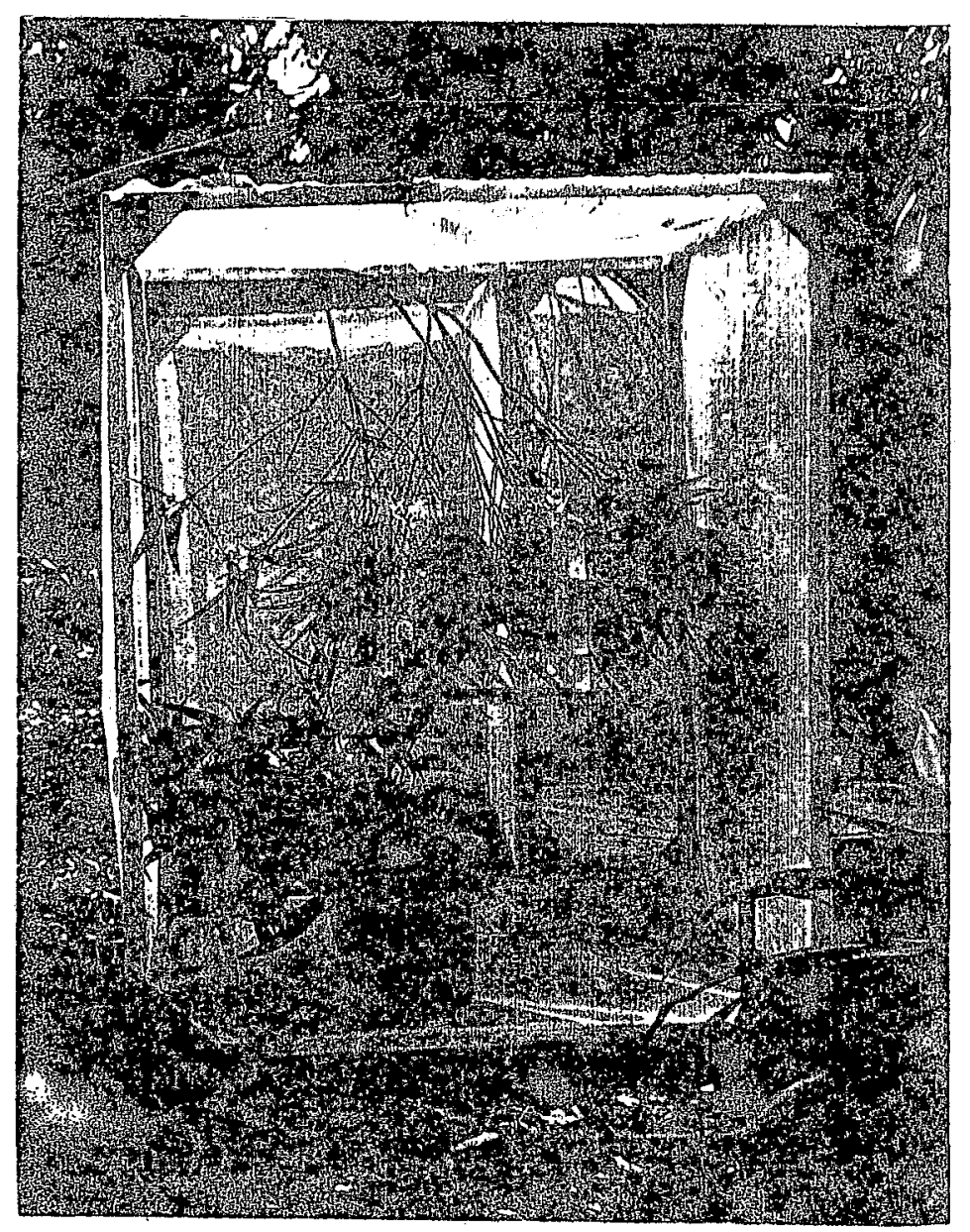


FIGURA 05 Enxerto heterozigoto para albinismo com todos tratamentos de engaiolamento ins talados, em Pomar de Sementes de E.gran dis.

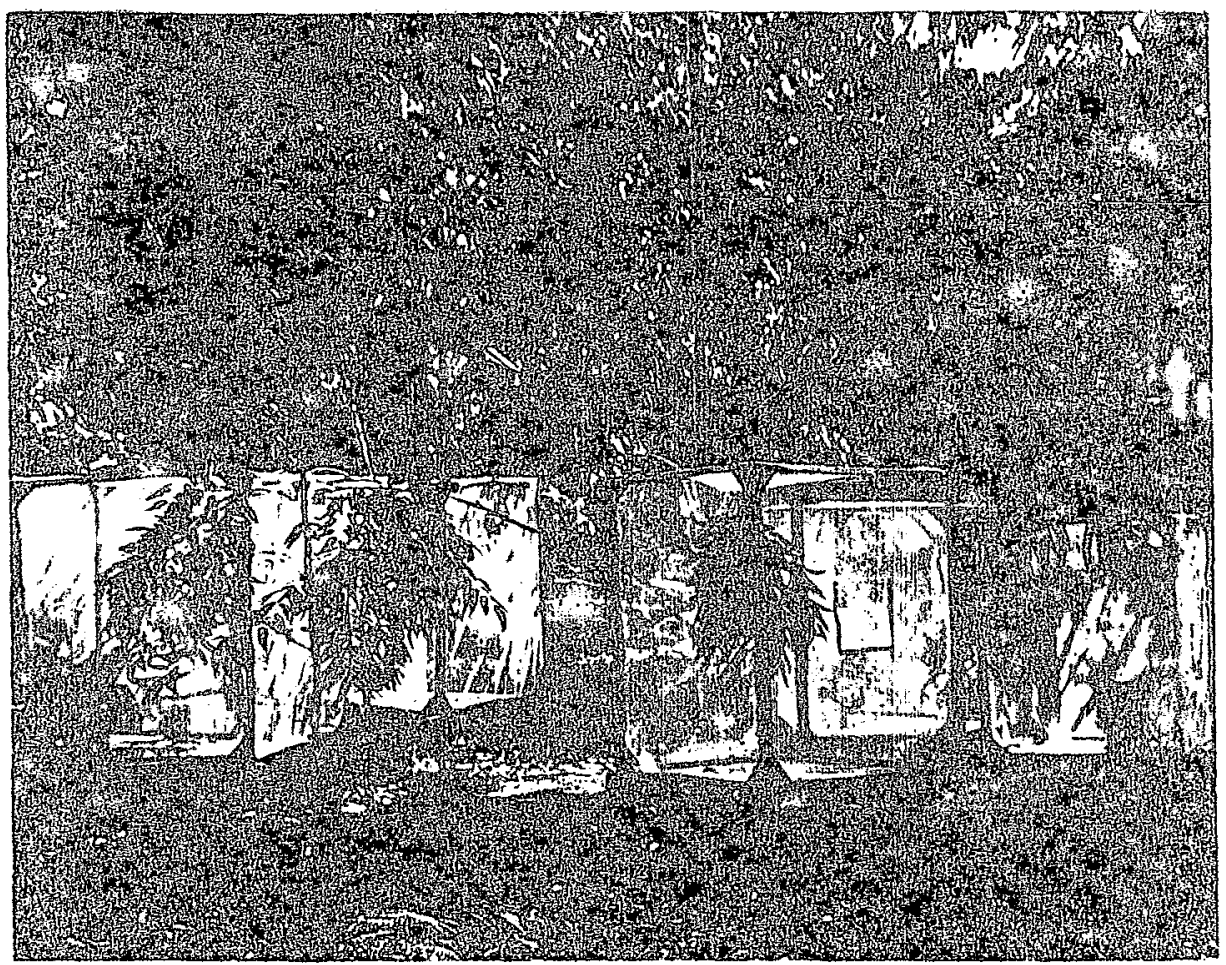


Os ramos de enxertos heterozigotos, antes de se rem introduzidos nas gaiolas, passaram por uma inspeção para e liminação de todas as flores, restando somente os botões flo rais, independente do estāgio de desenvolvimento.

Após a montagem das gaiolas, de acordo com os tra tamentos, foram introduzidos os insetos dos tratamentos corres pondentes.

o inseto de segunda maior frequência, Astylus va riegatus, não teve a sua frequência constatada em rede entomoló gica como os denais insetos, pelo fato desta espécie pertencer à ordem Coleoptera, possuindo pernas que se prendem firmemente às superfícies, o que inviabiliza o uso de tais redes. Portan to, para efeito de se constatar a frequência desta espécie, utị lizou-se da captura manual e sistemātica em nove ramos de três ārvores escolhidas ao acaso na população.

A captura acima citada, constou na retirada manu al de todos indivíduos da espécie dos ramos marcados, em iperioo dos regulares, nos intervalos de captura.

Desta forma, a amostragem descrita acusou 17 in divíduos em mëdia por dia e por ramo, que foi utilizado como nū mero de insetos por gaiola. Quanto ao inseto de primeira maior carga de pólen (Apis mellifera), o nümero determinado para en gaiolamento, a princi̊pio, foi determinado por média diāria do inseto de 3 (três) dias, resultando em 2 indivíduos por gaiola inicialmente. 
O ambiente limitado das gaiolas induzia a tentą tiva de fuga da A. mellifera do interior das mesmas, o que re duzia o trabalho do inseto, com relação a visitação das flores Em função disso, o número inicial do inseto foi multiplicado por três, como forma de compensar essa perda de atividades do inseto, sendo, portanto, engaiolados 6 individuos de Apis mel lifera e 17 indivíduos de Astylus variegatus por tratamento.

Após instalação da experimentação, os tratamen tos receberam manutenção em intervalo de tempo regular de dois dias, com a substituição eventual de insetos mortos e recoloca ção de ramos de clones homozigotos quando as anteriores já hạ viam completado o florescimento.

Após o completo florescimento dos ramos engaiola dos, as gaiolas foram retiradas e,por fim,coletou-se os frutos dos diversos tratamentos que tiveram suas sementes devidamente analisadas no Laboratório de Sementes Florestais da ESALQ-SP.

Com a colheita dos frutos por repetições e trata mentos, foram obtidos dados referentes à quantidade de semen tes por quilograma, número total de sementes germinadas, núme ro de plântulas anormais e número de plântulas albinas que foo ram submetidas à anālise estatística para verificação dos eféi tos de cada tratamento.

o aspecto das plântulas albinas observadas 'são as apresentadas na Figura 06, onde as plântulas além de não 
Plântulas albinas obtidas a partir de en gaiolamento de ramos de enxertosheterozigo tos para albinismo, em Pomar de Sementes de $E$. grandis.

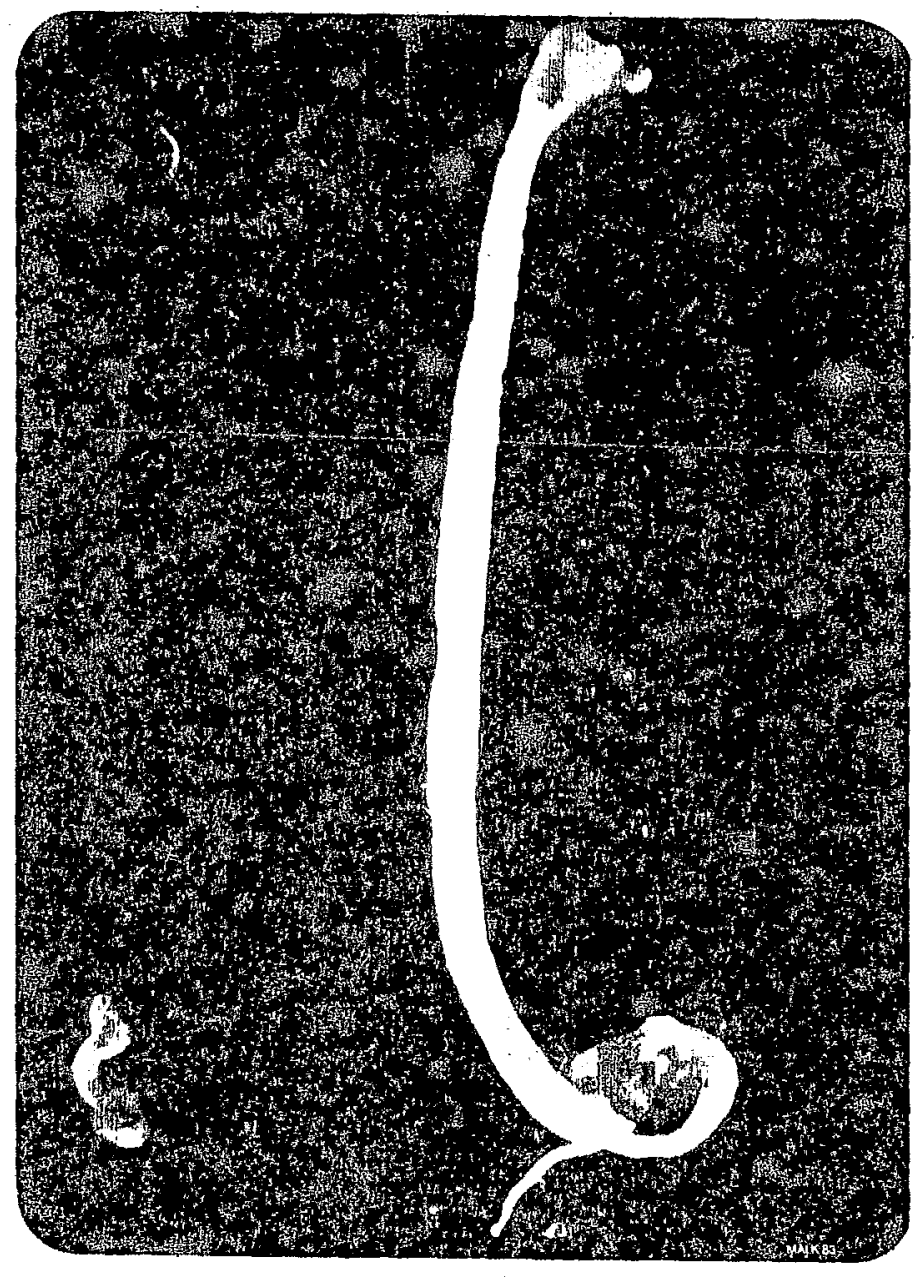


apresentarem clorofila, apresentaram anomalias em termos de tama nho do hipocótilo e tamanho de raíz reduzido ou ausente.

Foram consideradas plântulas anormais, as plântulas clorofiladas que apresentaram anomalias em termos de nümero de co tilédones, comprimento do hipocótilo e tamanho de raíz, que va riou desde ausente até menores que a metade do comprimento do hi pocótilo, até a ausência total de raíz.

\section{b - Anālise estatistica dos dados}

Os dados referentes ao engaiolamento de ramos e in setos necessitaram ser transformados, segundo recomendações de SOKAL e ROHLF (1969). Os dados referentes a produção de sementes por quilograma e totais de germinação foram transformados para $\sqrt{\mathrm{x}}$; os dados referentes às porcentagens de plântulas anormais e porcentagens de plântulas albinas foram convertidas para arco $\operatorname{sen} \sqrt{\frac{P}{100}}$.

Os dados transformados foram então analisados " pelo delineamento de Blocos Casualisados e os contrastes entre as mee dias dos tratamentos para a mesma característica foram obtidos pe lo teste de Duncan. 
A baixa frequência de clones heterozigotos era espe rada, na medida em que as plântulas albinas não se desenvolvem, morrendo logo após a germinação e, portanto, a frequência dessas plântulas depende basicamente da ocorrência de auto-fecundação das plantas heterozigotas e/ou dos raros cruzamentos entre elas.

Portanto, esses valores estão de acordo com o pro cesso de seleção natural, apresentado por METTLER e GREGG (1973), onde os autores demonstram que, no caso da eliminação total dos homozigotos recessivos, a frequência do alelo dominante $\vec{e}$ cada vez maior nessas populações.

o valor médio de individuos albinos produzidos também acusa um baixo valor como consequência do pröprio princípio de surgimento dessas plântulas, já descrito. Esse valor, como está apresentado sob forma de média, de vários enxertos, não se pres tou para a estimação de auto-fecundação na população estudada. A estimativa no caso é uma relação percentual entre plântulas nor mais e plântulas albinas, somente dos clones que as produziram.

Por sua vez, os valores da amplitude na produção de plântulas, entre 0,4 e 2,8 , demonstram claramente que há pequena variação no comportamento dos clones, cujas causas não foram estụ dadas.

Os valores obtidos, pela análise como foi realizada, prestaram-se para determinar quais são os clones heterozigotos pa ra albinismo e quais são os supostos clones homozigotos dominan tes por não produzirem plântulas albinas. 
4. RESULTADOS E DISCUSSÃO

4.1. Detecção de clones heterozigotos para albinismo e es timação de taxa de autofecundação.

4.1.1. Produção de plântulas albinas.

Os resultados dos testes de germinação de semen tes dos clones do Pomar de Sementes podem ser vistos no Anexo 01 e a classificação quantitativa dos clones quanto à capaci caade de produção de plântulas albinas é apresentada na Tabela 01 .

Os dados da germinação de sementes, individualí zados por enxertos do pomar de sementes, revelaram valores bas tante elevados para número de clones homozigotos, na ordem de $92,9 \%$, e, por conseguinte, valores bastante reduzidos para nụ mero de clones heterozigotos para albinismo na ordem de $7,1 \%$ do total. 


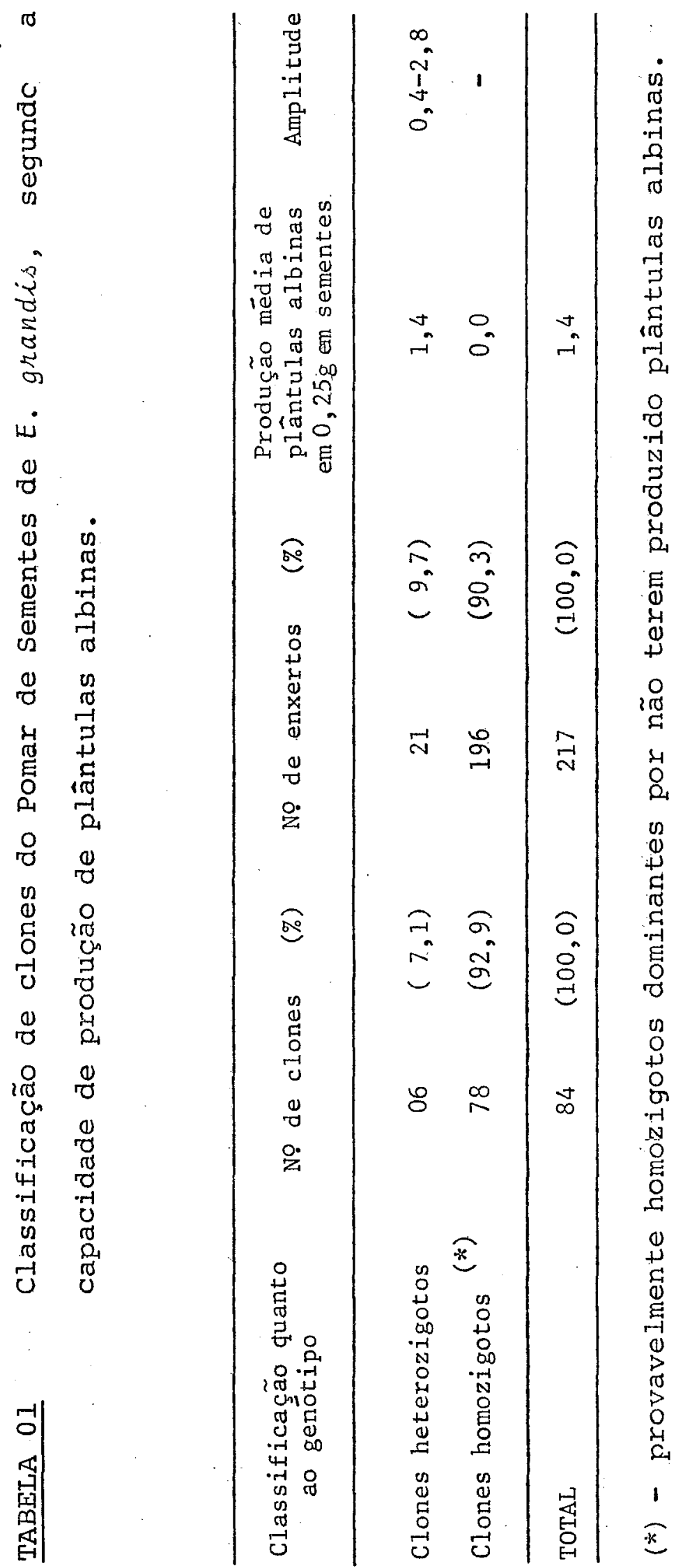


Os valores médios gerais de germinação e percenta gens respectivas para plântulas normais, plântulas anormais e plântulas albinas podem ser vistas na Tabela 02 .

o valor total de germinação para polinização livre, em duas repetições de $0,25 \mathrm{~g}$ de sementes por enxerto, apresentou média de 955.480 sementes viáveis por quilograma. Este valor a presenta-se equivalente em relação ao valor de 904.897 sementes por quilograma para o E. grandis, citado por MORA et alii (1980). 

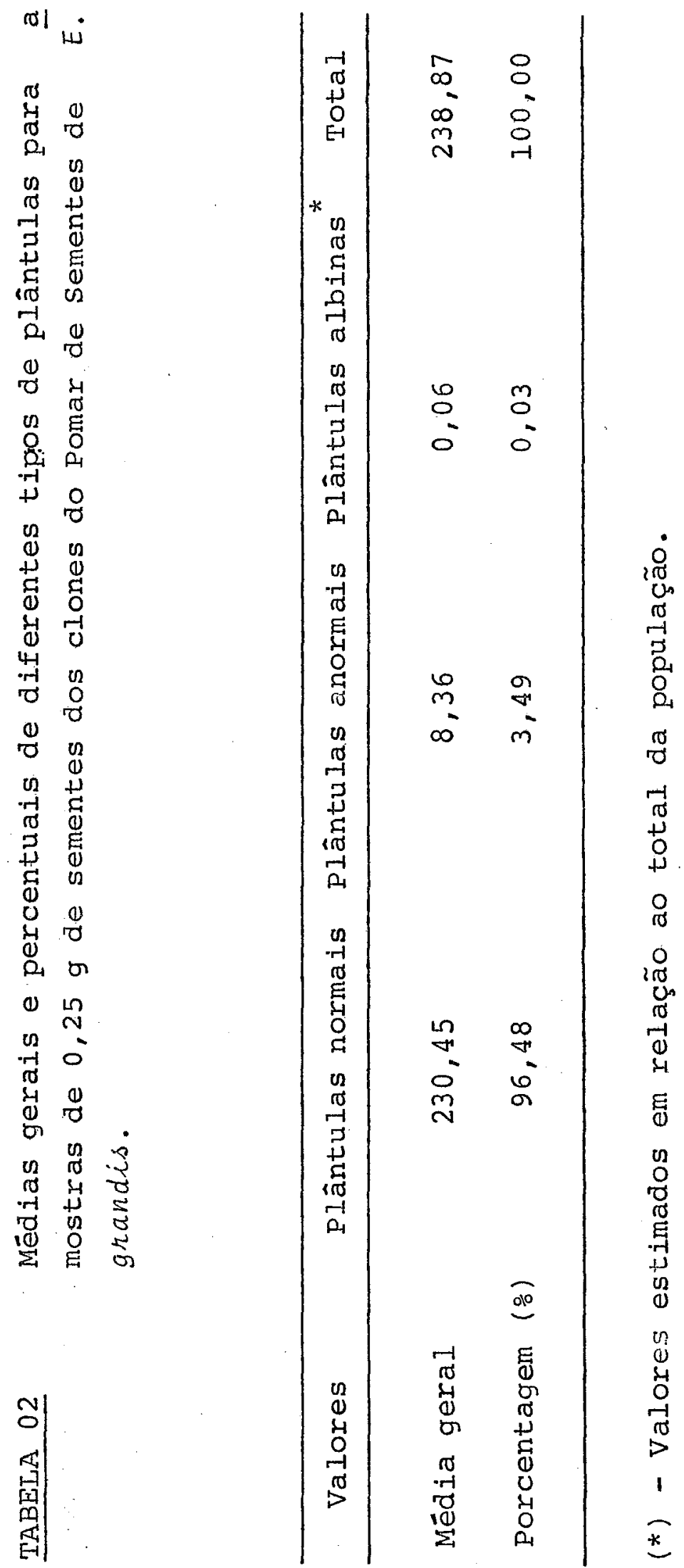
Os valores percentuais de produção de plântulas anormais e plântulas albinas, respectivamente de $3,49 \%$ e $0,03 \%$, podem ser considerados inexpressivos em relação aos $96,48 \%$, de plântulas normais.

4.1.2. Estimação da Taxa de Auto-fecundação

A estimação da taxa de auto-fecundação no pomar de Sementes foi efetuada considerando-se apenas os resultados refe rentes aos clones heterozigotos para albinismo, apresentados na Tabela 03. 


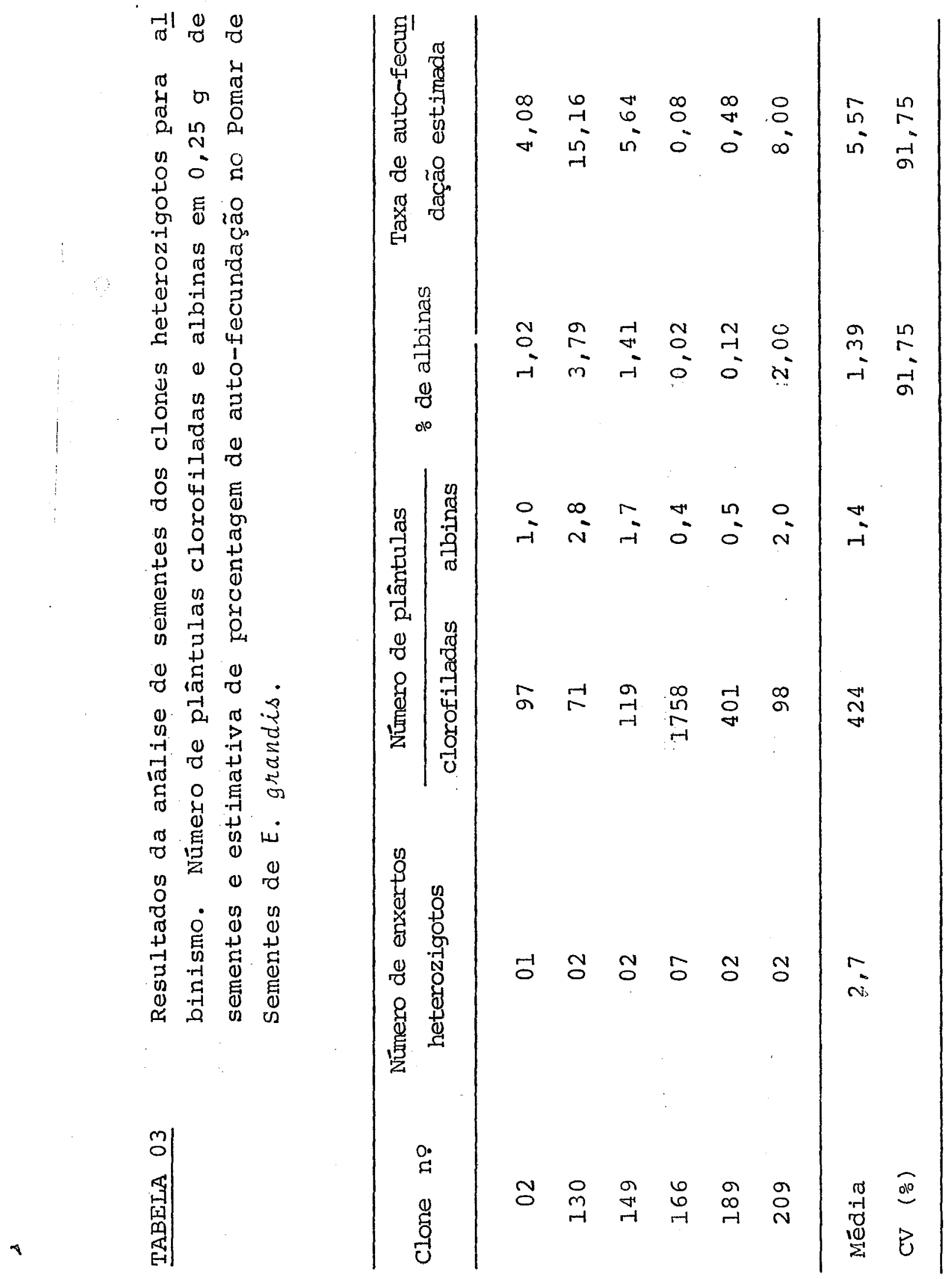


Do total de 84 clones e 217 enxertos analisados, foi verificada a presença de somente 6 clones heterozigotos para albinismo. Esses clones estão representados no Pomar de Semen tes com 16 enxertos, perfazendo a média de 2,7 enxertos por clo ne na geração estudada.

Os valores listados na Tabela 03 revelaram uma al ta variação dos clones em relação a taxa de auto-fecundação, com coeficiente de variação de $91,75 \circ$.

: Pela Figura 03, observa-se que, casualmente, al guns enxertos heterozigotos foram plantados bastante próximos en tre si. Porëm, os resultados da análise das sementes demonstram que o clone número 130, de maior taxa de auto-fecundação, está totalmente isolado de outros heterozigotos e, consequlentemente, a sua produção de albinos pode ser atribuída à sua capacidade de auto-fecundação:

o clone de número 166, por sua vez, teve dois enxer tos localizados juntos a outros dois enxertos do clone de nümero 209. Na análise de sementes, o primeiro apresentou a menor taxa de auto-fecundação $(0,08 \%)$, enquanto o segundo apresentou a se gunda maior taxa de auto-fecundação $(8,00 \%)$.

Pelos resultados dos très clones citados, pode-se notar então que não hã associação entre distâncias entre enxex tos heterozigotos e produção de plântulas albinas e que, portan to, o surgimento dessas plântulas deve-se a capacidade do enxer to em se auto fecundar. 
Ainda, pelos resultados contidos na Tabela 03, ve rificou-se que as menores frequências de plântulas albinas foram observadas nos clones que produziram a maior quantidade de plân tulas normais, enquanto as maiores freqüencias de plântulas albị nas ocorreram nos clones com menor quantidade de plântulas nor mais. Estes resultados estão de acordo com HODGSON (1976), que verificou o aumento de plântulas anormais como consequência de auto-fecundação em $E$. grandis.

o valor médio de taxa de auto-fecundação de 5,57\% quando utilizado para cálculo do coeficiente de endogamia, segun do a fórmula proposta por FALCONER (1960), revela um valor apro ximado de 0,03 para a geração seguinte. Segundo KAGEYAMA (1981) esse valor é baixo e, portanto, não é preocupante a ponto de in duzir alguma depressão endogâmica significativa nessa geração.

Portanto, pode-se dizer que considerando apenas o albinismo como referência para análise da estrutura genética do Pomar de Sementes estudado, a manutenção da variabilidade genéti ca na população está garantida pela eficiência dos polinizadores atuantes, promovendo alta taxa de cruzamento, considerando que a espēcie é predominantemente alógama.

4.2. Avaliação da Entomofauna do Pomar de Sementes.

4.2.1. Quantificação dos Insetos e Cargas de Pólen.

A captura sistemătica de insetos no pomar de Semen tes, na região de florescimento das árvores, resultou em ' um 
total de 118 espécies visitadores, transportadores de pólen ou não transportadores, cuja relação ē apresentada no Anexo 02 .

Pela relação do Anexo 02, verifica-se que a fiuna do Pomar de Sementes é constituĩda unicamente por insetos, não havendo outras classes, como os pássaros, citado por CHRISTENSEN (1971) como responsáveis em parte pela polinização dos eucalíp tos.

Ainda com relação ao Anexo 02, verificou-se que a mesma è bem mais extensa do que as 34 espēcies verificadas por BERTI FILHO (1981), presentes nas regiões de flores e frutos dos eucaliptos no Brasil.

Do total das 118 espēcies de insetos capturados, temos a seguinte quantificação por ordem: Hymenoptera, 29 espẹ cies; Lepidoptera, 19 espēcies; Diptera, 46 espécies; Coleop tera, 12 espēcies; Homoptera, 6 espēcies e Hemiptera, 6 espēcies.

Da relação das 118 espécies, foram constatadas prẹ sença de pölen em 26 espēcies assim distribuỉas: Hymenoptera, 9 espēcies; Lepidoptera, 3 espēcies; Diptera, 10 espécies; Co leoptera, 4 espécies, conforme a Tabela 04 .

Pela relação da Tabela 04 pode-se observar que, do total de 118 espēcies de insetos presentes no Pomar de Sementes, apenas 2.6 espécies participam com menor ou maior importância na atividade de transporte de pólen entre árvores, com média de 901.200 grãos de pölen agregado ao corpo por espëcie 'e 
frequência média de 10,09 indivỉduos por espécies.

Também pôde-se observar que, das 26 espécies da Tabela 04, há uma grande concentração de carga de pólen e ' fre quência em somente seis espécies: Apis mellifera com 19.468.600 grãos de pólen e frequência de 94,50 individuos; Trigona sp.com 1.808.000 grãos de pólen e 10,25 de frequência; Astylus variega tus com 1.346 .000 grãos de pólen e 84,75 de frequência; Bombus sp.com 276.600 grãos de pólen e 0,50 de freqtuencia; Ornidia obe sa com 152.600 grãos de pólen e 8,50 de freqtência e sinoeca sp. com 149.6000 grãos de pólen e 10,00 de freqtência. 
TABELA 04 Relação de insetos transportadores de pólen por or dem decrescente de carga de pólen. Médias de 4 di as de carga de pólen e de frequência de insetos.

\begin{tabular}{|c|c|c|c|}
\hline Inseto & Ordem & $\begin{array}{l}\text { Carga média de } \\
\text { pólen }(\times 20.000)\end{array}$ & $\begin{array}{l}\text { No médio de insetos } \\
\text { capturados/dia }\end{array}$ \\
\hline Apis mellifera & Hymenoptera & 973,43 & 94,50 \\
\hline Trigona sp. & Hymenoptera & 90,40 & 10,25 \\
\hline Astylus variegatus & Coleoptera & 67,30 & 84,75 \\
\hline Bombus sp. & Hymenoptera & 13,83 & 0,50 \\
\hline Ormidia obesa & Diptera & 7,63 & 8,50 \\
\hline Sinoeca sp. & Hymenoptera & 7,48 & 10,00 \\
\hline Riynchosciaria sp. & Diptera & 2,20 & 24,00 \\
\hline Trigona sp. & Hymenoptera & 1,85 & 2,50 \\
\hline Bombus morio & Hymenoptera & 1,43 & 0,30 \\
\hline Diptera (1) & Diptera & 1,08 & 0,50 \\
\hline Diabrotica speciosa & Coleoptera & 0,98 & 16,00 \\
\hline Diptera (2) & Diptera & 0,68 & 1,75 \\
\hline Campisomeris sp. & Hymenoptera & 0,58 & 0,30 \\
\hline Lepidoptera (I) & Lepidoptera & 0,50 & 0,50 \\
\hline Diptera (3) & Diptera & 0,33 & 0,30 \\
\hline Diptera (4) & Diptera & 0,33 & 0,30 \\
\hline Diptera (5) & Diptera & 0,25 & 1,30 \\
\hline Lagria villasa & Coleoptera & 0,18 & 1,50 \\
\hline Tomoplagia sp. & Diptera & 0,18 & 0,70 \\
\hline Hymenoptera & Fymenoptera & 0,18 & 0,30 \\
\hline Diptera (6) & Diptera & 0,18 & 0,30 \\
\hline Vespidae & Hymenoptera & 0,15 & 1,50 \\
\hline Coleoptera (1) & Coleoptera & 0,08 & 1,00 \\
\hline Anamia florella & Lepdoptera & 0,08 & 0,30 \\
\hline Salpingogastes sp. & Diptera & 0,08 & 0,30 \\
\hline Lepidoptera (2) & Lepidoptera & 0,08 & 0,25 \\
\hline TOTAL 26 & & 1171,47 & 262,40 \\
\hline Média por espécie & & 45,06 & 10,09 \\
\hline
\end{tabular}

Coeficiente de correlação entre carga mëdia de pólen e nümero médio de inse tos capturados: $r=0,76$ 
Os valores de carga de pölen e de frequência dos insetos em porcentagem do total observado, são apresentados na Tabela 05.

Pelos valores apresentados, verificou-se que, em termos de carga de pólen transportado, há a predominância da Apis mellifera, com 83,09\% do total observado. Desta forma, so mente $16,91 \%$ do pólen transportado pelos insetos cabe aos outros insetos do Pomar de Sementes.

Em contrapartida, na freqtência de insetos não foi observada a predomināncia da Apis mellifera, sendo que este inse to apresentou frequência próxima do Astylus variegatus, com $36,01 \%$ e $32,30 \%$, respectivamente, caracterizando dessa forma que há a predominância de frequência de duas espécies no Pomar de Se mentes.

o Bombus sp, apesar de sua baixa frequência, foi considerado pelo critério de carga de pólen como uma das espécí es importantes no Pomar de Sementes, pelo tamanho do seu corpo, capacidade de transporte de pólen e sua intensa movimentação en tre ärvores do Pomar. o coeficiente de correlação para carga de . pólen $\left(\frac{q}{8}\right)$ e frequência $\left(\frac{\circ}{8}\right)$ demonstra que há uma forte correlação entre essas duas caracteristicas $(r=0,76)$.

o Astylus variegatus, apesar da sua ótima frequên cia, relativa capacidade de transporte de pólen, apresentou uma quase total falta de mobilidade entre árvores do pomar de Semen tes, permanecendo durante horas na mesma inflorescência. 
contrário, nas outras cinco espēcies, o tempo observado foi em média de 2,5 a 3,8 segundos, conforme os valores da Tabela 06.

TABELA 05 Relação dos insetos mais importantes no Pomar de Se mentes de $E$. grandis com suas respectivas mẻdias de frequência e cargas de pólen transportados em por centagem.

\begin{tabular}{lcc}
\hline Espécie & Frequência (\%) & Carga de pólen (\%) \\
\hline Apis mellifera & 36,01 & 83,09 \\
Astylus variegatus & 32,30 & 5,74 \\
Trigona sp. & 3,91 & 7,72 \\
Bombus sp. & 0,19 & 1,18 \\
Ornidia obesa & 3,24 & 0,65 \\
Sinoeca sp. & 3,81 & 0,63 \\
Outros insetos & 20,54 & 0,99 \\
\hline Total & 100,00 & 100,00 \\
Média das espëcies & 16,50 & 13,24 \\
\hline
\end{tabular}

(*) - Mẻdia das cinco espécies, desconsiderando outros insetos. 
A classificação do A. variegatus como praga flores tal, baseia-se no fato do mesmo além do consumo de pólen, cons tituir-se em verdadeira barreira física aos outros insetos visi tadores de flores.

4.2.2. Comportamento dos Insetos nos diferentes Iocais do PO mar de Sementes e períodos do dia.

Pelas flutuações de populações de insetos nos lo cais do Pomar de Sementes e diferentes periodos do dia, observou -se que os insetos penetram uniformemente no Pomar de Sementes e que hâ uma tendência dos insetos em condicionar as frequências, em função das temperaturas dos diferentes perioodos dos dias.

Os valores relativos à frequência média de quatro dias de captura, dos seis principais insetos observados por pe rỉodos do dia e locais do Pomar, são relacionados na rabela 07. 
TABELA 06 Tempo de permanência mẻdia dos insetos na mesma flor, de E. grandis.

\begin{tabular}{lccc}
\hline \multicolumn{1}{c}{ Espécie } & No de observaçōes & $\begin{array}{c}\text { Tempo médio } \\
\text { permanência (seg) }\end{array}$ & Ampolitude \\
\hline Apis mellifera & 120 & 5,0 & $3-8$ \\
Trigona sp. & 45 & 4,0 & $2-7$ \\
Astylus variegatus & - & - & - \\
Bombus sp. & 4 & 3,0 & $2-4$ \\
Ormidia obesa & 27 & 4,1 & $2-7$ \\
Sinoeca sp. & 48 & 3,8 & $2-6$ \\
\hline Média & & 3,9 & $2,3-6,4$ \\
\hline
\end{tabular}

(*) - Tempo não determinãvel por falta quase absoluta de movi mentação do inseto.

(**) - Desconsiderando o Astylus variegatus.

Alèm do fato do Astylus variegatus ter sido citado como praga de flores de Eucalyptus por BERTI FILHO (1981), a fal ta de mobilidade do inseto faz com que na classificação estabe lecida o inseto em questão seja então desconsiderado como tal, apesar da sua frequência e sua capacidade de carga de pólen clas sificarem-no como o terceiro inseto mais importante. 
TABELA 07 Freqüência média de quatro dias de captura dos seis insetos mais importantes, nos periodos ida dia: e locais do Pomar.

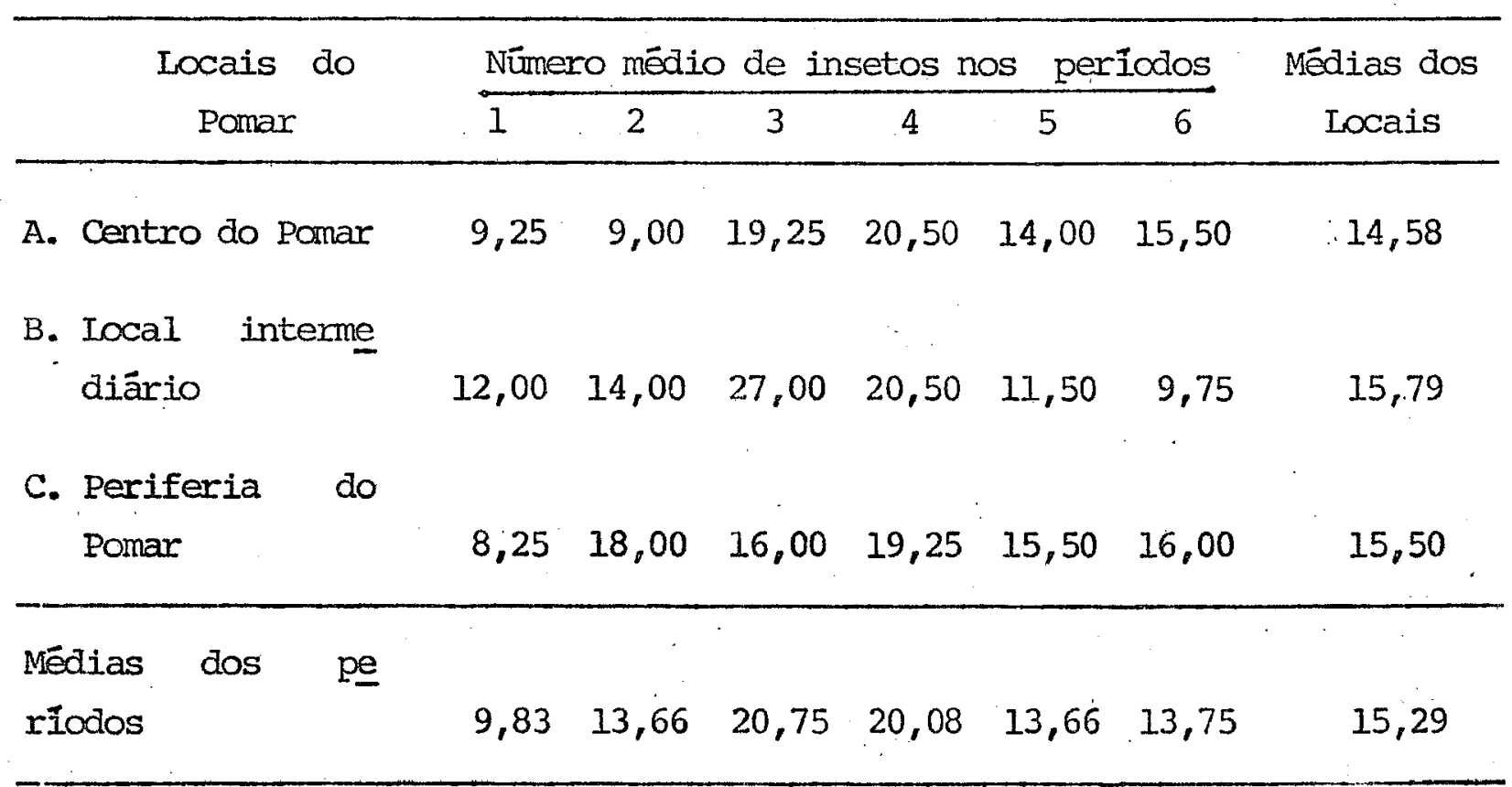

Periodos: 1 (7:00 às $8: 00 \mathrm{~h}) ; 2(8: 00$ às $10: 00 \mathrm{~h})$; 3) $(10: 00$ às $12: 00 \mathrm{~h})$; 4 (12:00 às $14: 00 \mathrm{~h}) ; 5$ (14:00 às $16: 00 \mathrm{~h}) ; 6$ (16:00 às 18:00h)

De acordo com os valores da Tabela 07, observa-se que hà um aumento gradativo e posterior decrēscimo da frequência de insetos com os periodos do dia, sugerindo que há uma correla ção positiva entre a frequthencia de insetos com $\circ$ aumento da tem peratura nos periodos do: dia. Este fato pode ser verificado na medida em que no periodo 1 (7:00 às 8.00h) observou-se a me nor freqthência de insetos, enquanto nos periodos 3 (10:00 às $12.00 \mathrm{~h})$ e $4(12: 00$ às $14: 00 \mathrm{~h})$ constataram-se as maiores frequên cias de insetos. 


\section{FIGURA 07}

$\because$

Frequência média de insetos e variação da temperatura no

Pomar de Sementes de E.grandis, nos periodos dos dias.

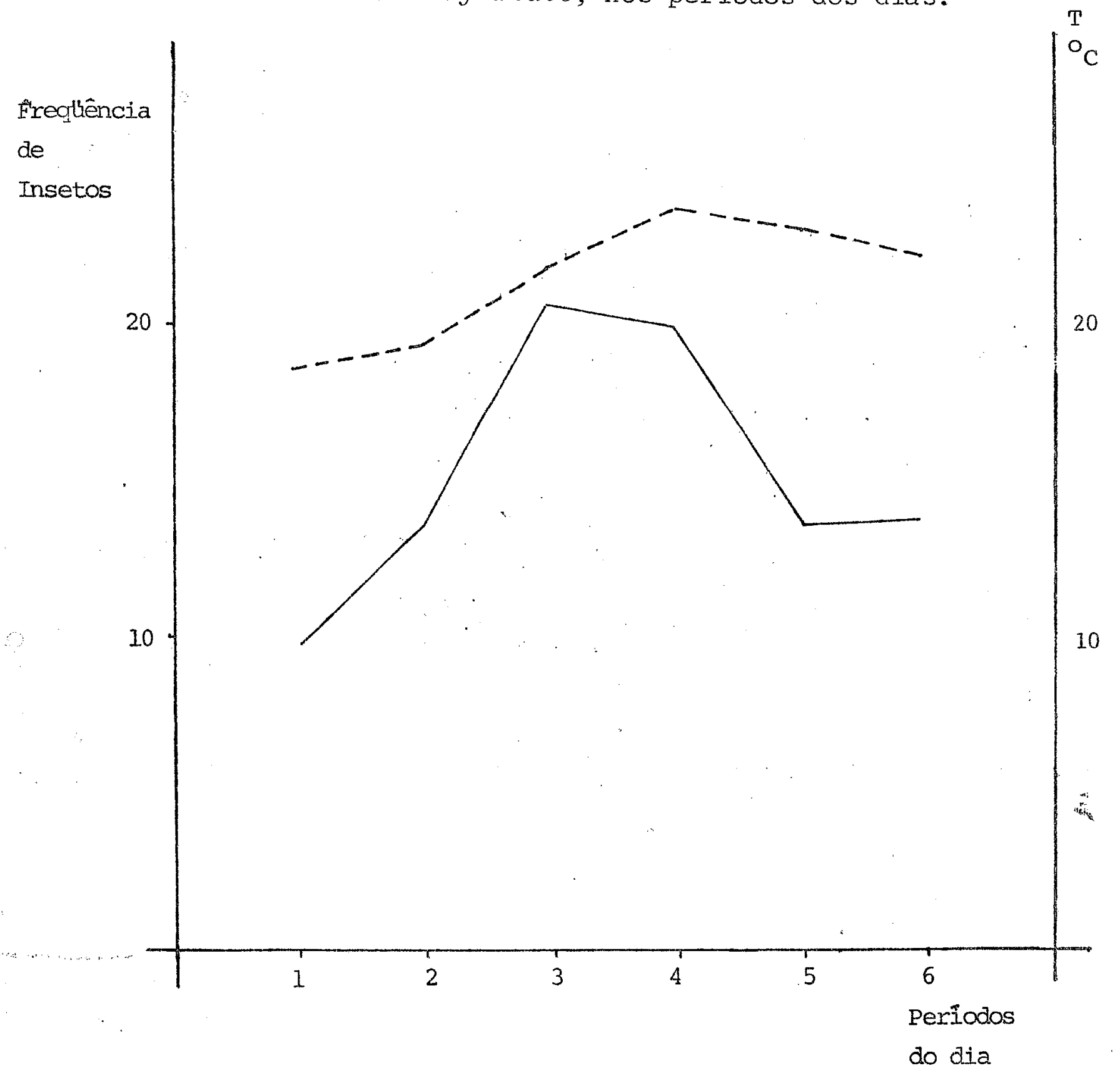

$\cdots-\cdots$ temperatura dos períodos do dia

= frequência de insetos 
Através da Tabela 08 e da Figura 07 pode-se visuali zar a associação entre as frequências médias de insetos e os res pectivos periodos do dia, assim como as temperaturas desses perío dos.

Como pode-se verificar, há uma nîtida associação en tre as frequências de insetos com o aumento das temperaturas nos períodos dos dias, excluindo-se no entanto dessa tendência as fre quências entre os períodos 5 e 6 , quando houve uma mudança na ten dência da curva, com estabilização da freqtência.

Portanto, apesar do valor da correlação $r=0,60$ da associação entre frequências de insetos e periodos do dia não a presentar significância, verifica-se nitidamente essa tendência pela Tabela 08 . 
Ainda os dados da Tabela 07, quando vistos sob 0 aspecto da frequência de insetos em relação aos locais de amos tragem no Pomar, não se verifica nenhuma tendência nîtida, suge rindo que a freqtiência dos insetos independem do ponto de amos tragem, e que a penetração de inseto no pomar de Sementes ocor re uniformemente, não havendo diferenças entre locais.

Os valores médios de frequência de insetos corre lacionados com as temperaturas médias dos periodos do dia são apresentados na Tabela 08 .

TABELA 08. Médias de frequência de insetos por temperaturas médias de 4 dias dos periodos de captura, no Pomar de sementes de-E. grandis.

\begin{tabular}{|c|c|c|c|c|c|c|}
\hline & & & eríodos & no & dia & \\
\hline & 1 & 2 & 3 & 4 & 5 & 6 \\
\hline $\begin{array}{l}\text { Freqtiencia } \\
\text { de insetos }\end{array}$ & 9,83 & 13,66 & 20,75 & 20,08 & 13,66 & 13,75 \\
\hline $\begin{array}{l}\text { Temperaturas } \\
\text { Médias - }\left({ }^{\circ} \mathrm{C}\right)\end{array}$ & 18,5 & 19,25 & 21,75 & 23,62 & 23,00 & 22,75 \\
\hline
\end{tabular}

Coeficiente de correlação linear "r" =0,60 ns

$t=1,5$

$r$ = coeficiente de correlação linear; ns = não significativos;

$t=$ teste $t$

Os valores de frequência de insetos quando correla cionados com as temperaturas médias dos perilodos do dia, 
apresentaram valores para coeficiente de correlação linear $(r=0,60)$ não significativo a nível de $5 \%$ pelo teste $t$. Desta forma, não se pode afirmar que há uma correlação entre as duas ocorrências verificadas, podendo-se apenas sugerir que há uma tendência de aumento na frequência dos insetos com o aumento da temperatura nos periodos do dia.

Ainda com relação aos valores da Tabela 08, obser va-se que há uma estabilidade de temperatura no interior do Po mar entre os periodos 5 e 6 . A frequência de insetos nestes pe ríodos apresentou então uma pequena elevação e o desaparecimento completo dos insetos verificou-se com o ocaso do dia, em torno do final do período 6 , aproximadamente às 18:00h.

A Figura 08 possibilita a visualização da associą ção entre frequências mēdias de insetos e as cargas de pólen mëdias correspondentes.

A figura em questão demonstra que, no caso da asso ciação entre frequências de insetos e cargas de pólen, hā uma coreelação bastante forte com significância a 1\%. Desta forma pode-se afirmar que a população de pólen que está sendo movimen tada no interior do Pomar, entre diferentes flores e diferentes árvores, depende da quantidade de insetos que estão efetivamente realizando este trabalho. 
o comportamento geral das frequências e insetos mais importantes nos periodos do dia, locais do pomar e dias de captura e suas interações são apresentados na Tabela 09, com seus respectivos valores de $F$ da análise da variância. 
F'IGURA 08 Associação entre freqthência médias de insetos mais importantes no Pomar de Sementes de E. gran dis e suas respectivas cargas médias de pólen.

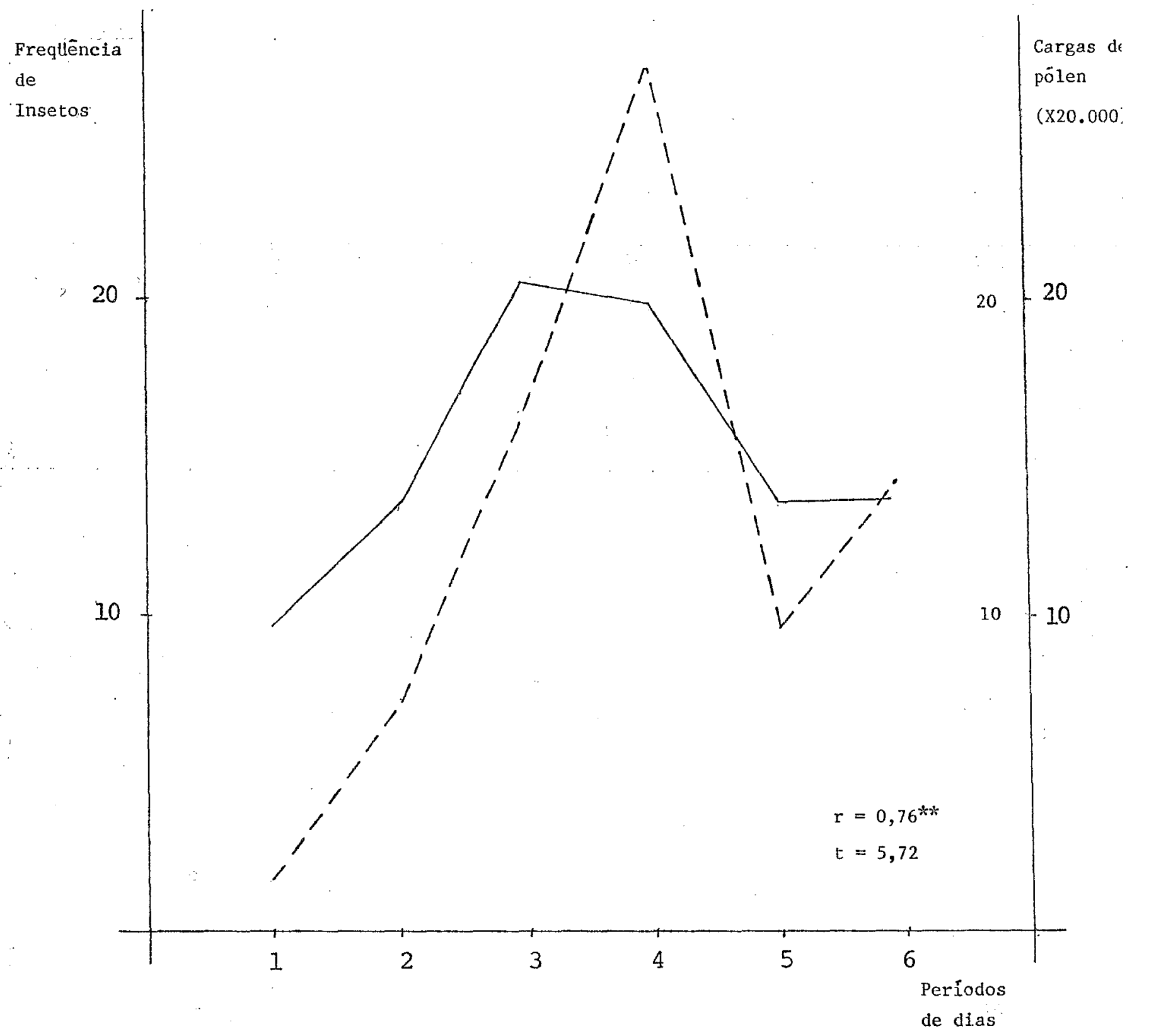

$$
\begin{aligned}
r & =\text { coeficiente de correlação linear } \\
t & =\text { teste } " \mathrm{t} " \\
* * & =\text { siggifificāncia a } 1 \% \\
& =\text { frequencia de insetos } \\
--- & =\text { cargas de pólen }
\end{aligned}
$$


TABELA 09 Valores de $F$ para anālise de variância conjunta de médias dos seis principais insetos nos dias de cap tura, periodos do dia e locais do Pomar.

\begin{tabular}{lc}
\hline Fonte de variação & Valores de F \\
\hline Periodos no dia & $3,01^{*}$ \\
Locais no Pomar & $3,28 \mathrm{~ns}$ \\
Dias de captura & $4,20^{*}$ \\
Locais X períodos & $1,48 \mathrm{~ns}$ \\
Periodos X dias & $2,78 *$ \\
Locais X dias & $1,11 \mathrm{~ns}$ \\
\hline CV (\%) = 38,82 & \\
$*$ = significância ao nivel de 5\%; ns $=$ não sig \\
$\quad$ nificativo
\end{tabular}

Pela Tabela 09, verificou-se valores significati vos de F, a nível de 5\%, para períodos no dia, dias de captura e na interação entre dias de captura e períodos do dia. No en tanto, não foram detectadas diferenças entre locais no Pomar e suas interações com períodos do dia e dias de captura.

Com base nesses resultados, verificou-se que exis tem variações entre os dias de captura e dentro dos periodos do dia, mas não entre os locais no Pomar. Tambēm, os locais se com portaram regularmente nos diferentes dias e periodos; os perio dos variaram com os diferentes dias de captura. 
Esses resultados comprovaram, então, o princípio da uniformidade na distribuição de insetos no pomar, e que este principio ainda independe da quantidade de insetos nos diferen tes dias.

4.3. Resultados referentes a verificação dos insetos como po linizadores.

4.3.1. Produção de sementes em ramos engaiolados.

Os resultados de quantidade e qualidade de semen tes produzidas, a partir do engaiolamento de ramos de enxeritos he terozigotos para albinismo, são apresentados na Tabela 10 .

Por esses resultacios verificou-se que os ramos 1 i vres produziram as maiores quantidades de sementes, com as maio res quantidades de sementes germinadas. Os ramos engaiolados sem ramos de outros enxertos e sem insetos não produziram sementes, reforçando a alogamia e a entomofilia para a espécie, concordan do com FAEGRI e Van der PIJL (1971) e PRYOR e BODEN (1967).

Na condição de engaiolamento com ramos de outros enxertos, o Astylus se comportou melhor que a Apis, provavelmen te devido ao "stress" provocado na segunda, com a situação anor mal de engaiolamento.

Os ramos engaiolados sem ramos de outros enxertos foram eficientes na produção de sementes somente com o Astylus. mostrando que nessas condições pode ocorrer a autofertilização. 
A mistura entre os dois insetos não alterou o re sultado da espëcie de melhor comportamento, no caso o Astylus. 


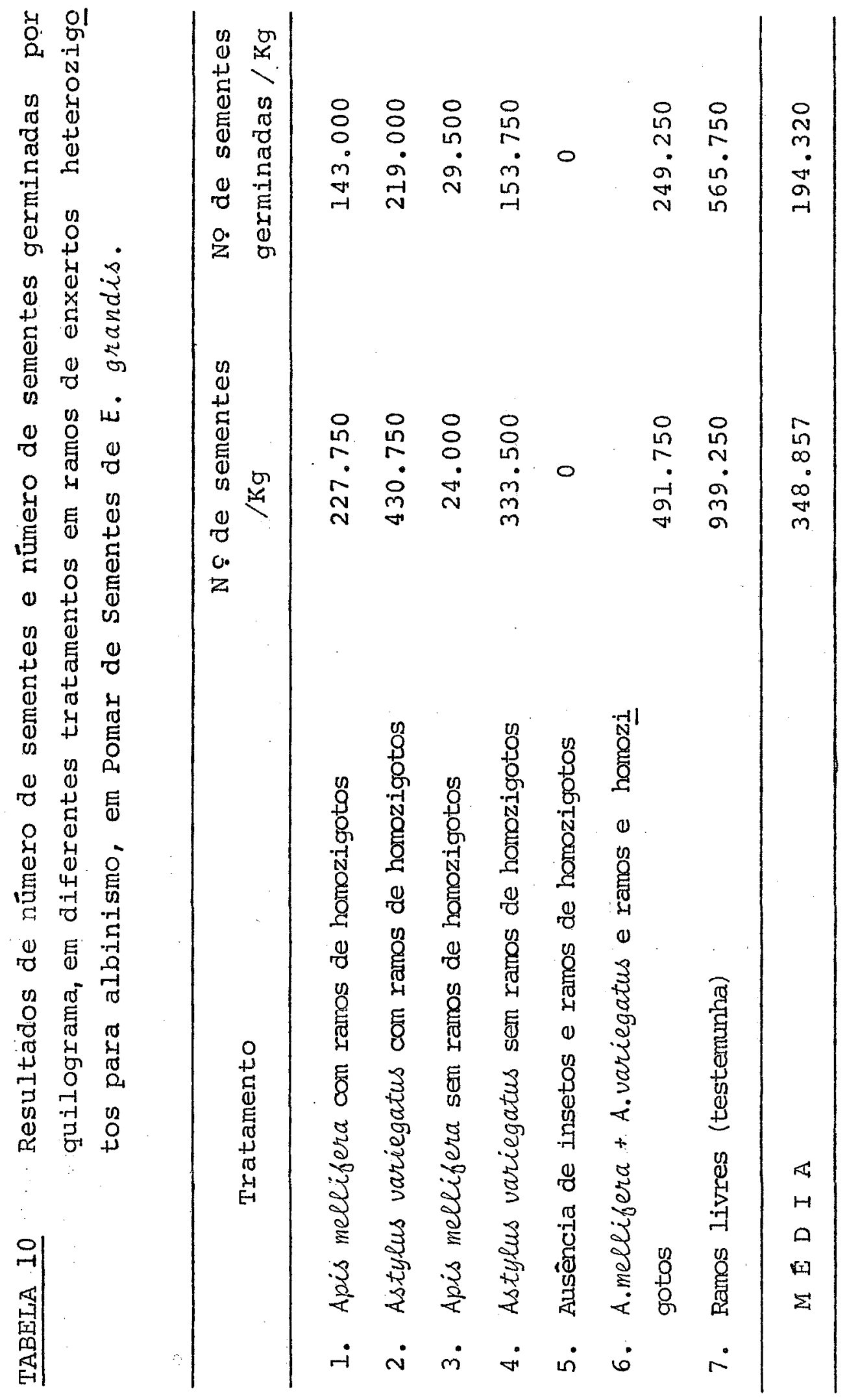


4.3.2. Efeitos dos insetos na auto-fecundação no Pomar de se mentes

Os dados de produção de plântulas albinas e esțimati vas de auto-fecundação, nos diferentes tratamentos em ramos en gaiolados de enxertos heterozigotos, são apresentados na Tabela 02 .

Tomando como referencial os ramos livres (testemu nha), verifica-se que a estimativa de auto-polinização foi muito branda (1,24\%), bem abaixo da mëdia encontrada para todo o pomar de Sementes, na geração anterior, que foi de 5,57\%. Esses dados estão abaixo da média revelada na literatura: KRUG e ALVES(1949), 23\%; FLORENCE (1969), 100\%; ELDRIDGE (1976), 8 a 28\%; e HODGSON $(1976), 10$ a $38 \%$

Quando se colocou ramos homozigotos para albinismo nos tratamentos, a estimativa de auto-fecundação foi maior para Astylus $(6,84 \%)$ do que para Apis $(2,80 \%)$, mostrando a maior efi ciência da Apis em promover fecundação cruzada, em relação ao pou co mövel Astylus.

Quando não se colocaram ramos homozigotos nos trata mentos, a taxa de auto-fecundação estimada para Astylus aumentou significativamente $(20,16 \%)$, reforçando a tendência deste inseto provocar maior auto-fecundação.

Os ramos engaiolados com os dois insetos seguiram os resultados do Astylus para a estimativa de auto-fecundação. Os ra mos engaiolados sem insetos e sem ramos homozigotos não produzi ram sementes, não possibilitando a estimativa de auto-fecundação. 
(Tratamentos 3 e 4), os resultados esperados eram de 100\% de auto -fecundação. Portanto, os resultados de 3,36\% e 20,16\% sugerem que a estimativa de auto-fecundação somente pela porcentagem de plân tulas albinas é insuficiente para o caso, necessitando-se então de outros genes marcadores auxiliares para uma maior precisão dos re sultados.

TABELA 11 Valores médios de auto-fecundação estimada por tratą mento em Pomar de Sementes de $E$. grandis.

Tratamentos

Total Germinação
\% albinas

: Auto-fecundação*

1. Apis mellifera com ramos ho mozigotos

143,00

0,70

2,8

2. Astylus variegatus com ra mos homozigotos

219,00

1,71

6,84

3. A. mellifera sem ramos homo zigotos

$$
29,50
$$

0,84

3,36

4. A. variegatus sem ramos ho miozigotos

153,75

5,04

20,16

5. Ausência de insetos e de ra mos de homozigotos

0

0

0

6. A. mellifera + A. variegatus e ramos de homozigotos

249,25

2,00

8,00

7. Ramos livres (testemunha)

565,75

0,31

1,24

MEDIA

194,32

1,51

6,06

(*) - auto-fecundação estimada por ter sido considerada somente plântulas albinas. 
A análise de variância dos valores referentes a produ ção de sementes, dos tratamentos de engaiolamento de ramos de en xertos heterozigotos para albinismo, apresentou os valores constan tes na Tabela 12 .

T'ABELA 12 Quadro resumo para valores de $F$ da anālise de variân cia para resultacios dos tratamentos de engaiolamento de ramos de enxertos heterozigotos para albinismo, em Pomar de Sementes Clonal de E. grandis.

\begin{tabular}{|c|c|c|}
\hline Características & $\begin{array}{l}\text { Valores de } F \\
\text { entre tratamentos }\end{array}$ & $\mathrm{CV}\left({ }^{\circ}\right)$ \\
\hline NO Sementes $/ \mathrm{kg}$ & $2,81^{*}$ & 72,18 \\
\hline $\begin{array}{l}\text { Total germinação } \\
\text { (no de viāveis } / \mathrm{kg} \text { ) }\end{array}$ & $7,57^{* *}$ & 58,35 \\
\hline ㅇ de anormais & $0,56 \mathrm{~ns}$ & 78,62 \\
\hline \% de albinos & $2,14 \mathrm{~ns}$ & 97,07 \\
\hline
\end{tabular}

\footnotetext{
(*) - significativo a 5\%; (**) - significativo a $1 \%$; ns = não significativo e $\mathrm{CV}(\%)=$ coeficiente de variação experi mental em $\frac{}{2}$.
}

Pela Tabela 12, verifica-se que houve diferenças sig hificativas ao nível de 5\% para produção de número de sementes por quilogramas eaonỉvel de 1\% para número de sementes viáveis por qui lograma. Não se observou significância para produção de plântulas anormais e plântulas albinas, apesar das médias terem : diferido substancialmente. 
Os coeficientes de variação obtidos na experimenta ção demonstraram valores bastante elevados em relação as tradicio nais experimentações na ārea de Silvicultura. Porém, esses valo res de coeficientes de variação experimentais não podem ser consi derados como critërio de julgamento da validade e precisão da ex perimentação, devido a prōpria experimentação conduzida fugir aos radrões de experimentações usuais, por estarem envolvidos inúme ros fatores que são incontrolāveis ao experimentador.

Os fatores que afetaram a experimentação foram: a im possibilidade de controle do pesquisador em relação ao acaso na visitação dos insetos às flores; a modificação no hābito de visi tação dos insetos às flores quando no engaiolamento dos ramos; a possibilidade da ação de outros genes deletērios albinos e aborto de ovos e frutos pelas mais diferentes causas, afetando assim as frequências esperadas em diferentes tipos de plântulas.

Pelos motivos expostos pode-se considerar que o va lor de $F$ igual a 2,14 para porcentagem de plântulas albinas, não significativo a 5\%, porém significativo a 10\%, segundo valor tabe lado em BENNETT e FRANKLIN (1954), bem como os altos valores de cọeficientes de variação podem ser aceitáveis, dada as peculiaridades da experimentação.

As diferenças entre mëdias de tratamentos para dife rentes características são apresentadas na Tabela 13, pelo Teste de Duncan ao nĩvel de 5\% de significância. 
TABELA 13 Tabela de diferenças entre mēdias de tratamentos pelo Teste de Duncan a nível de 5\%, para resultados de engaiolamento de ramos de enxertos heterozigotos para albinismo, em Pomar de Sementes Clonal dé $E$. grandis

Tratamentos

No Sementes/Kg

Total anormais

albinas

Germinação

1. Apis mellifera com ra mos homozigotos

a

$\mathrm{b}$

a

C

2. Astylus variegatus com ramos homozigotos

a

$\mathrm{b}$

a

$\mathrm{b}$

3. Apis sem ramos homozi gotos

$\mathrm{b}$

C

a

d

4. Astylus sem ramos ho mozigotos

a

b

a

a

5. Ausência de insetos e ramos homozigotos

$\mathrm{b}$

C

$\mathrm{b}$

e

6. Apis + Astylus : e ra mos homozigotos

a

$\mathrm{b}$

a

b $\quad c$

7. Ramos livres (teste munha)

a

a

a

d

Os tratamentos com a mesma letra não diferem entre si, ao nível de 5\%

Pelos constrastes obtidos pode-se verificar que em termos de produção de nümero de sementes por quilograma, somente ps. tratamentos (3) - Apis sem ramos de enxertos homozigotos e o tratamento sem insetos equivalem-se e,portanto, diferenciam-se dos 
demais, demonstrando que a presença ou aușência de insetos em ra mos isolados é estatisticamente indiferente. Porém, na prática ob servou-se que no tratamento sem insetos houve total ausência. de produção de sementes, enquanto que a Apis mellifiera, mesmo em iso lamento e ramos isolados è capaz de produzir sementes. Portanto, mesmo que estatisticamente os valores não difiram ente si, hã que se considerar que a Apis mellibera apresentou capacidade de promo ver auto-fecundação nessas condições e, consequentemente, podem promover auto-fecundação em ärvores isoladas ou muito distantes entre si em populações florestais.

A capacidade de produção de sementes viāveis/kg tam bẹm acompanhou a tendência da produção de nūmero de sementes/kg, excluindo-se porém a produção do Tratamento 7-ramos com poliniza ção livre, o que era esperado na medida em que essa característi ca revela sucesso de polinização e,como tal, os ramos não engaio lados naturalmente deveriam apresentar a melhor performance para essa característica, como realmente ocorreu, conforme HODGSON(1976).

No tocante à produção de plântulas anormais, todos tratamentos equivaleram-se estatisticamente entre si, exceto tratamento sem insetos (Tratamento 5), o que não era o esperado considerando-se que hä uma relação entre nümero de plântulas anor mais e auto-fecundação, segundo HODGSON (1976). Em relação aos re sultados da Tabela 11, os valores médios demonstram que a maior produção de plântulas anormais foi produzida pelos ramos livres e o menor valor para Apis mellifera sem a presença de ramos homozi gotos para cruzamentos, que também apresentaram a maior e a menor 
produção de número de sementes por quilograma, respectivamente.

Como os valores relativos ao nümero de pläntulas a normais não acompanham as relações de nümero de sementes por qui lograma e número de plãntulas albinas, a frequência de plântulas anormais está provavelmente mais correlacionada a outros fatores genéticos da população do que a ocorrência de auto-fecundação das árvores da população.

Em relação à produção de plântulas albinas, e conse quentemente a taxa de auto-fecundação estimada, verificou-se que houve diferenças entre as médias dos tratamentos, onde houve seme Ihança entre A. mellifera com ramos para cruzamentos (Tratamento 1) e quando associada a A. variegatus (Tratamento 6) que por sua vez foi semelhante a $A$. variegatus com ramos para cruzamentos. Po reem, não se verificou semelhanças entre o primeiro e o terceiro tratamentos, respectivamente. Esses resultados por $\mathrm{si}$ indicam que $\circ$ A. variegatus, mesmo que em nümero reduzido e associado a A. mellifera, manteve a sua alta capacidade de promover a auto-fe cundação e,portanto,é prejudicial ao Pomar de sementes.

Por outro lado, os resultados da Apis mellifera: sem łamos para cruzementos apresentou resultados semelhantes aos ra mos livres, o que sugere que este inseto, apesar da sua alta capa cidade de promover cruzamentos entre plantas, verificado pela bai xa produção de plântulas albinas e, consequentemente, promovendo baixa taxa de auto-fecundação, comporta-se dentro de um padrão não esperado para insetos polinizadores. 
Obviamente os tratamentos de ramos sem insetos (Tra tamento 5) e o A. variegatus apresentaram diferenças entre si e com os demais tratamentos em termos de produção de plântulas albi nas. O primeiro pela não produção de sementes e o segundo pela prōpria alta capacidade de auto-fecundação. 
5. CONCLUSÕES

Os dados obtidos nas três fase de estudo no Pomar de Sementes de Eucalyptus grandis permitem as seguintes conclusões:

a. O Pomar de Sementes de E. grandis do estudo apresenta 7,1\% de clones heterozigotos para albinismo e, consegdentemente, 92,98 de clones homozigotos dominantes para essa caracterîs tica;

p. o valor da taxa de auto-fecundação média estimada, somente pela característica de produção de plântulas albinas, : è : de 5,57.\%, valor este que representa um coeficiente de endogamia aproximado de 0,03 ;

c. na avaliação da entomofauna da região das flores dos enxer tos do Pomar de Sementes, constata-se que apesar do grande número de insetos presentes, somente alguns poucos participa ram efetivamente da movimentação de pólen entre flores e enxertos do Pomar de Sementes; 
d. a Apis mellifera éoinseto mais frequente e com maior carga

- de pólen. o inseto de segunda maior frequência, o Astylus variegatus, è citado como praga florestal e pela frequência semelhante da Apis mellifera constitui-se em competidor por pólen em potencial com os polinizadores, afetando dessa for ma a polinização nos enxertos do Pomar de Sementes;

e. em relação à frequência de insetos no Pomar de Sementes, a penetração dos mesmos se dá de forma homogênea em nümero de espëcies e nümero de espēcimes em toda a ärea, garantindo dessa forma a homogeneidade na qualidade das sementes em to dos os enxertos que constituem o Pomar de sementes;

f. pelos valores de coeficientes de correlação linear obtidos, evidencia-se que a frequência de insetos no Pomar está mais associada à oferta de pólen e néctar, do que pelas temperatu ras dos períodos dos dias, na medida em que na primeira si tuação verificou-se a existência de correlação positiva sig nificativa, enquanto que na segunda situação, apesar do coe ficiente de correlação positiva, não houve significância;

g. os insetos em testes para polinização controlada, a Apis me lifera possibilita a produção de sementes mesmo em ramos iso lados e sem cruzamentos, naturalmente promovendo a auto-po linização a nível de flores de mesmo ramo; o Astylus variega tus quando no engaiolamento, apresenta produção de sementes 
maior que a Apis mellifera porém, em contrapartida, tambēm a presenta a maior taxa de auto-fecundação;

h. a não, ocorrência de 100\% de auto-fecundação em ramos isola dos com insetos sugere que a expressão da endogamia não po de ser evidenciada somente pela freqtência de plântulas albi nas. 
REFERENCIAS BIBLIOGRAFICAS

AMARAL, E. O papel das abelhas na polinização - Revista da Agri cultura, Piracicaba, 1951. 26 (112): 179-184.

AMARAI, E. Utilidade das abelhas na polinização. São paulo A grỉcola - são Paulo, 1960. 2 (18):22-23.

ANDRADE, E.N. de. O eucalipto 2a. Ed. Jundiaí, CPEF. são Paü 10, 1960. 486-505.

ASHTON, D.H. Studies of flowering behaviour in Eucalyptus reg nans F. Mueel. Australian Journal of Botany., Melbourne, 1975. $23: 399-411$

BENNETT, A.C. e N.I. FRANKLIN. Statistical analisis in chemis try and the chemical industry. John wiley and Sons, Inc. New York. 1934.698-711.

BERTI FILHO, E. Insetos associados a plantações de espécies do gênero Eucalyptus nos Estados da Bahia, Espírito Santo, Mato Grosso do Sul, Minas Gerais e São Paulo.Piracicaba,ESALQ/USP, 1981. 176p. (Tese de Livre Docência, Escola Superior de Agri cultura "Iuiz de Queiroz"/USP). 
BOLAND, D. Abnormal Eucalyptus leucoxylon F. Muell. Seedlings. Australian Forest Research Camberra, 1977. (7):151:61.

BRASIL. MINISTERIO DA AGRICULTURA. ESCRITORIO DE METEOROĹOGIA Escritório Central de Planejamento e Controle-ECEPLAN. Atlas Climatológico do Brasil (Reedição de Mapas Selecionados). Rio de Janeiro, 1969.

BURGUESS, I.P. A ocorrência natural de Eucalyptus grandis, seu padrão de distribuição nas florestas naturais, suas caracterís ticas e conservação. 1983. In: Simpósio IUFRo. Aguas de são Pedro. Silvicultura. São Paulo, 35:397-399.

CARR, D.J. e G.M., CARR. Developmental Morfology of the floral organs of Eucalyptus. I The inflorescence. Australian Jour ial of Botany, Melbourne, 1959. I (2):109-141.

CHRISTENSEN, P.S. Simulation of see fal in Karri. Australian Forestry. Camberra, 1971. 35 (3):182-190.

ELDRIDGE, K.G. Breeding systems, variation and genetic impro vement of tropical eucaliptis. In: BURLEY, J. \& STYLES, B. T. Tropical Trees. London, Academic Press, 1976. 101-08.

FALCONER, D.S. Introduction to quantitative genetics. New York, Ronald Press, 1960. 365p.

FLORENCE, R.G. A comparative study of flowering and seed produc tion in six blackbutt (Eucalyptus pilulairs Sm.) forest stantds Australian Forestry. Camberra, 1964. 28:23-33. 
FRANKEL, R. e GALUN, E. Pollination mechanisms, reprodution and plant breeding. Spinger-Verlag. New York, 1977. 281p.

FREE, J.B. Management of honey bee colonies for crop pollina tion. Report Rothanested Experimental Station. Acádemic Press London. $1970.542 \mathrm{p}$.

GOMES, F.P. Curso de estatística experimental. Livraria Nobel. São Paulo, 1976. 430p.

HALL, N., R.D. JOHNSTON, G.M. CHIPPENDALE. Forest Tress of Austra 1ia. Camberra, 1970. 344pp.

HODGSON, L.M. Some Aspects of Flowering and reproductive Behaviour in Eucalyptus grandis (Hill) Maiden at J.D.M. (Keet Forest Research Station (Formerly Zomerkomst Forest Research Station). I. Flowering, controlled pollination methods, polination and re ceptivily. South Africa Foresty Journal. Johannessbur, 1976. (97): $18-28$.

JACOBS, M.R. Eucalyptus for planting. FAO. Forestry series No 11 Roma, 1979, 677p.

KAGEYAMA, P.Y. Variação genētica entre procedências de Pinus $\underline{0}$ ocarpa Schiede na região de Agudos-SP. Piracicaba, 1977. 83p (Dissertação de Mestrado. Escola Superior de Agricultura "Luiz de Queiroz"/USP).

KAGEYAMA, P.Y. Variação genētica em progênie de uma população de Eucalyptus grandis Hill ex Maiden. Piracicaba, 1980.125p. (Dou torado-Escola Superior de Agxicultura"Luiz de Queiroz"/USP). 
KAGEYAMA, P.Y. Endogamia em Espēcies Florestais. Série Técnica IPEF, Piracicaba, 1987. 2(8).40p.

KRUG, C.A. \& ALVES, A.S. Eucalyptus improvement. Journal of Heredity. Baltimore, 1949. 40:133-139.

METTLER, L.E. \& GREGG, T.G. 1973. Genētica de populações e evo Iução. EDUSP/POLIGONO, São Paulo, 1973. 262p.

MORA, A.L., ZANI FILHO, e KAGEYAMA, P.Y. Perspectivas da utili zação do beneficiamento de sementes de Eucalyptus. Circular Técnica IPEF, Piracicaba, 1980. 102.4p.

MORA, A.I., PINTO JR. J.E., FONSECA, S.M. da e KAGEYAMA P.Y. AS pectos da Produção de Sementes de Espëcies Florestais. Série Técnica IPEF, Piracicaba, 1981. 2 (6) 60p.

MORAES, M.L.T. de. Variação genética da densidade básica da ma

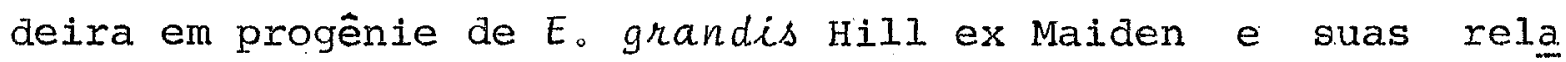
ções com as características de crescimento. Piracicaba, 1987 115p. (Mestrado-Escola Superior de Agricultura "Luiz de Quei roz"/USP).

PACHECO, I.A. Polinização de Eucalyptus saligna Smith (Myrta ceae) por Apis mellifera L., 1758 (Hymenoptera, Apidae). Pira cicaba, 1982. 87p. (Dissertação de Mestrado. Escola Superior de Agricultura "Luiz de Queiroz"/USP).

PRYOR, L.D. Biology of Eucalyptis. Studies in Biology no 61. The Camelot Press Ltd. London, 1976. 82p. 
PRYOR, I.D. Los hábitos reproductivos del eucaliptos. Unasylva, Roma, 1978. $30(119 / 120): 42-6$.

C PRYOR, L.D. \& BODEN, R.W. Blowflies as pollinators in prodúcing Eucalyptus seed. Australian Journal of Science. Camberra 1967. $\underline{24}(7): 326$.

SANTOS, C.F. de O. Principais tipos de pólen colctados pelas abelhas Apis mellifera $\mathrm{I}$. no período de maio a novembro de 1959. 으 solo, Piracicaba, 1962. 느(1):97-103.

SOKAL, R.R. \& ROHLF, J.F. Biometry. The principles and pratice of statistics in biological research. Second edition. W.H. Freeman and Companhy. San Francisco, 1969. 427-428.

STANLEY, R.G. \& LINSKENS, H.F. Pollen: biology, biochemistry try and management. Springer-Verlag, New York, 1974. 307p.

TUITE, J. Plant Pathological Methods. Burgess Pub. Co., Minnea polis, 1969. 239pp.

VENKATESH, C.S. and SHARMA, V.K. Some usual seedings of Eucalyp tus, their genetic significance and value in breeding. Silvae Genética, Frankfurt, 1974. 23(4):120-4.

VENKATESH, C.S. \& VAKSHASYA, R.K. Effects of selfing, Crossing and Interspecific Hybridization in Eucalyptus camaldulensis Dehn. in World Consultation on Forest Tree Breeding, 3, Cam berra, 21-26 March 1977. Proceedings. CSIRO. Camberra, 1978. $\underline{2}: 683: 692$.

VAN WYK, G. Imbreeding effects on Eucalyptus grandis families with different degree of relatedness. In Simposio IUFRo. Aguas de São Pedro, 1980. 8p. 


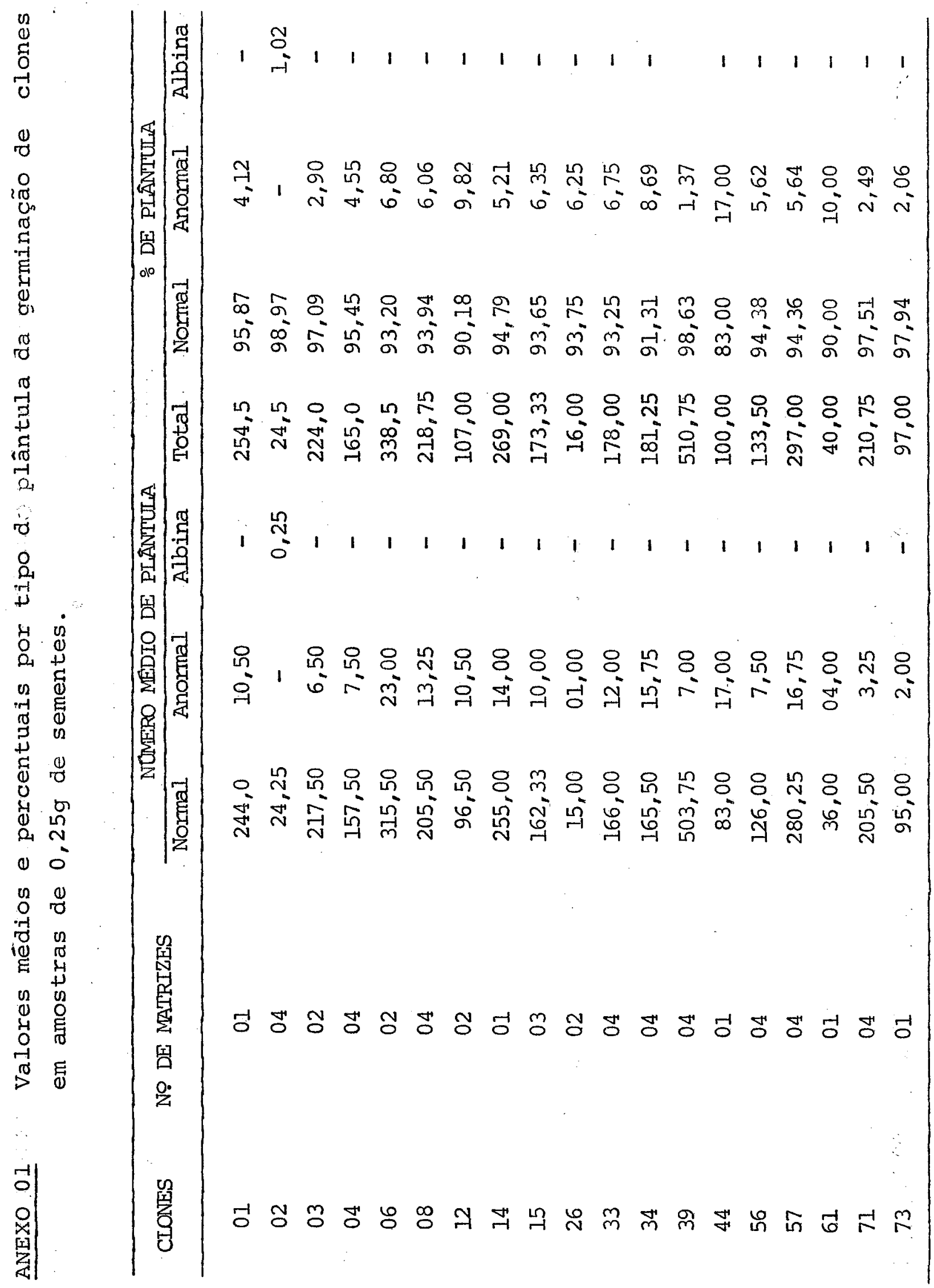




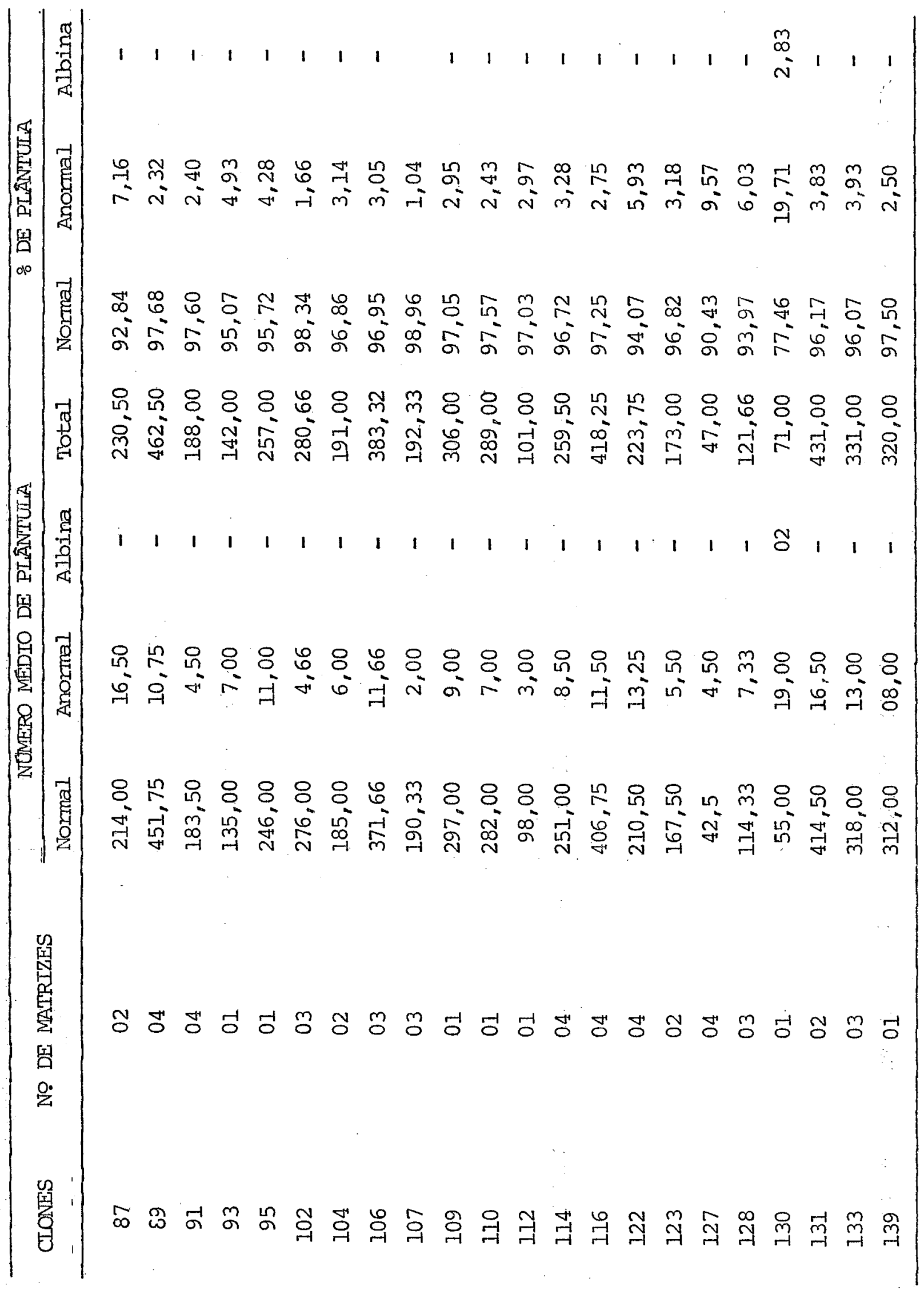




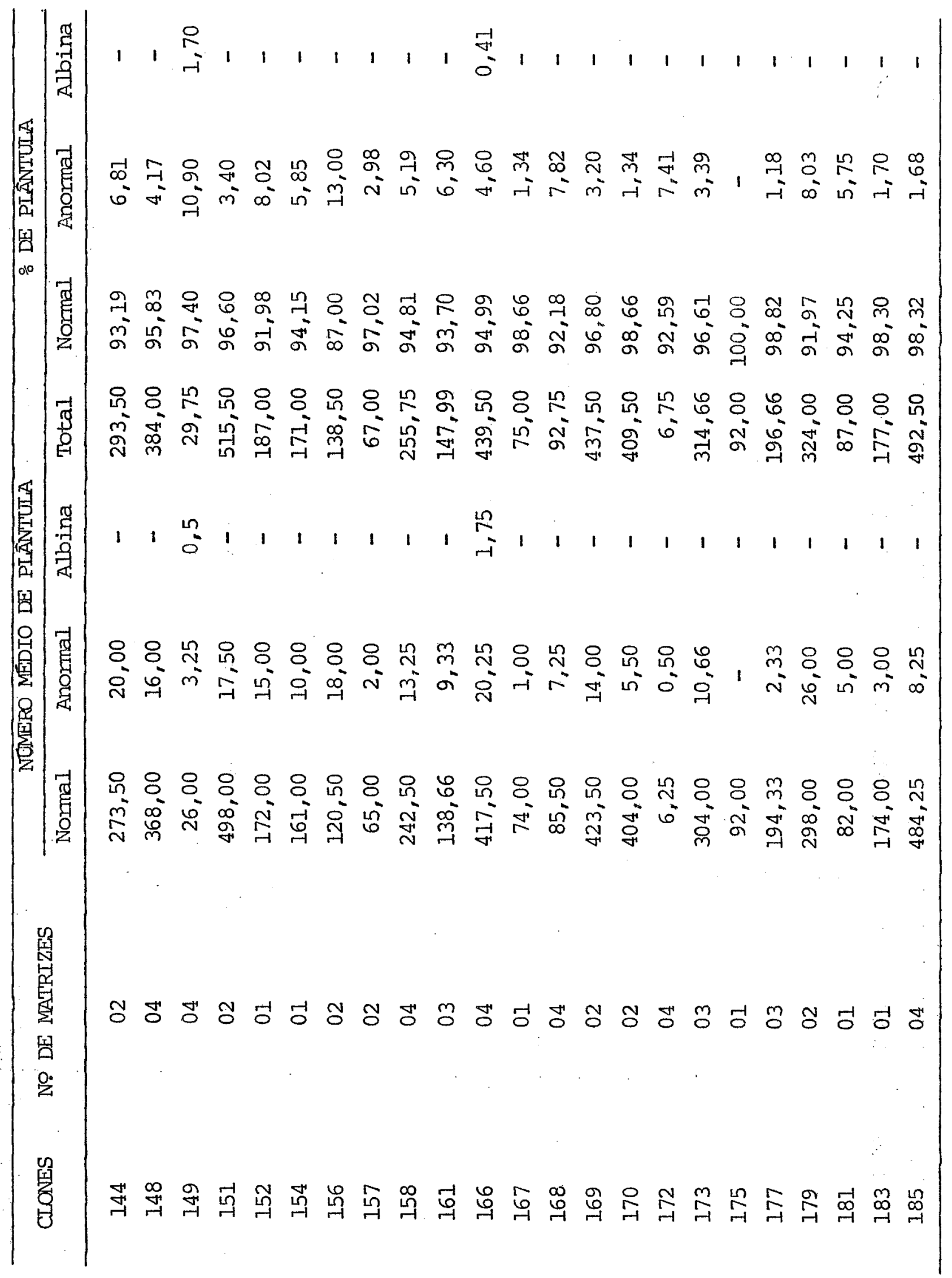


.84 .

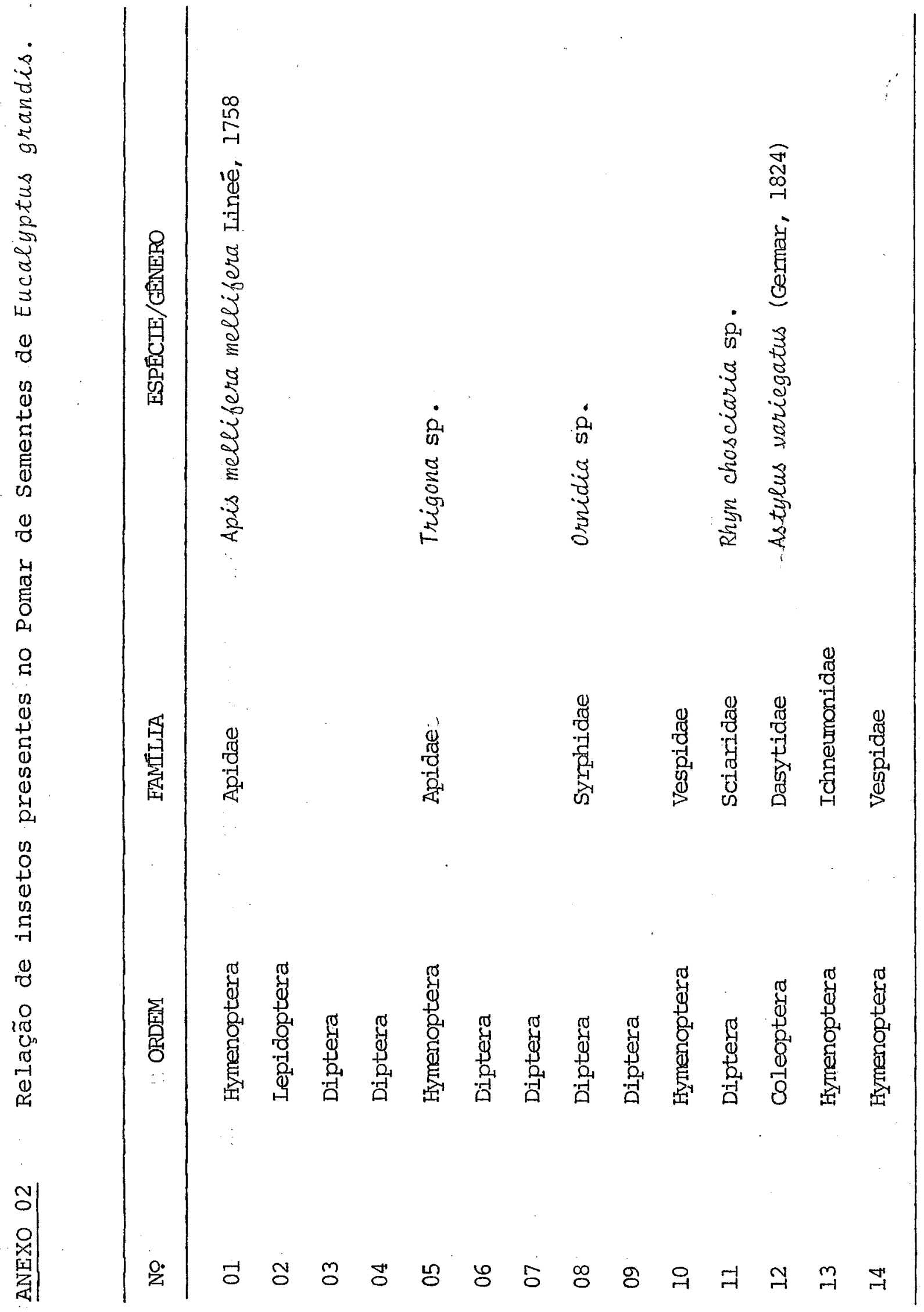




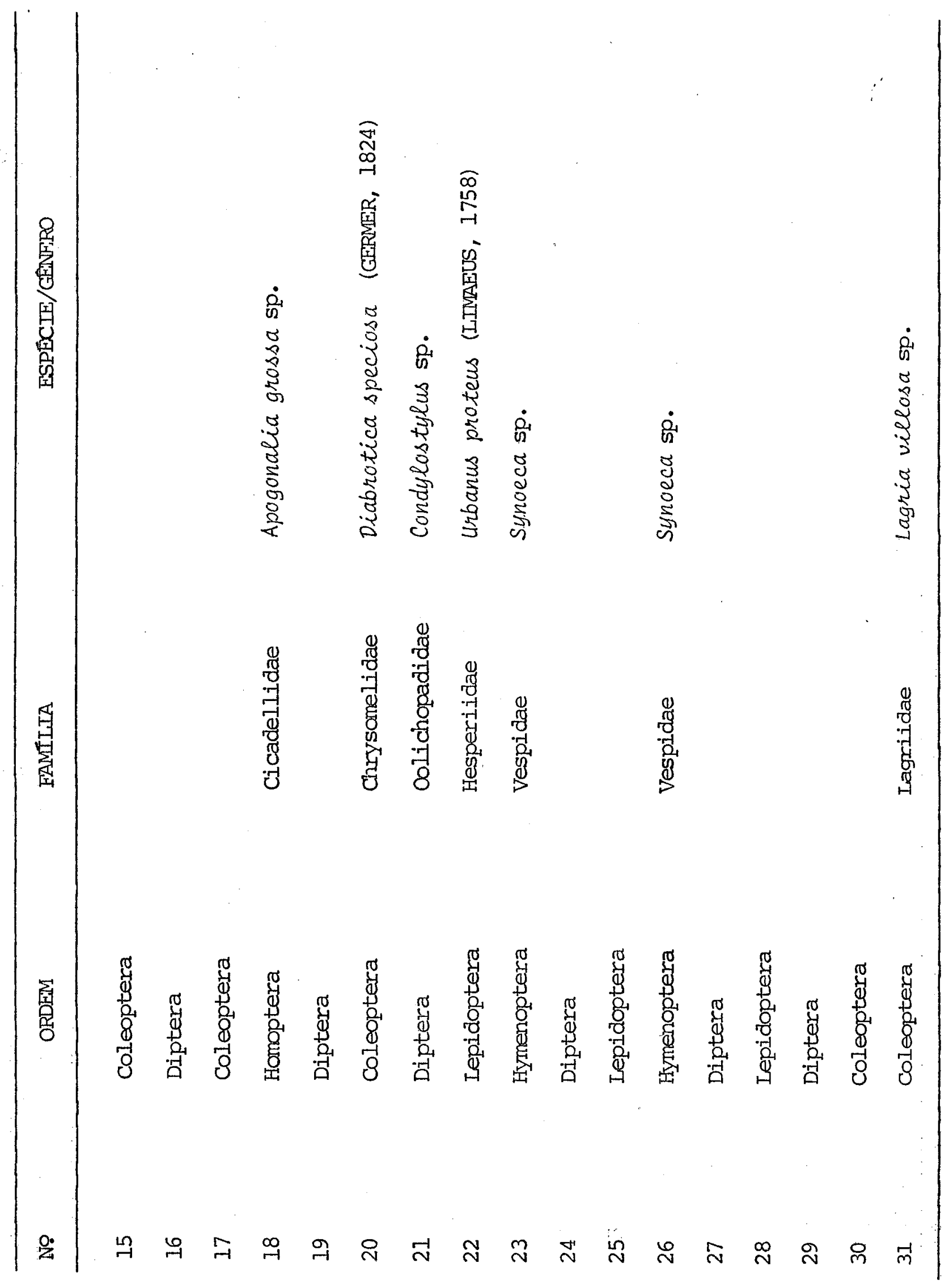




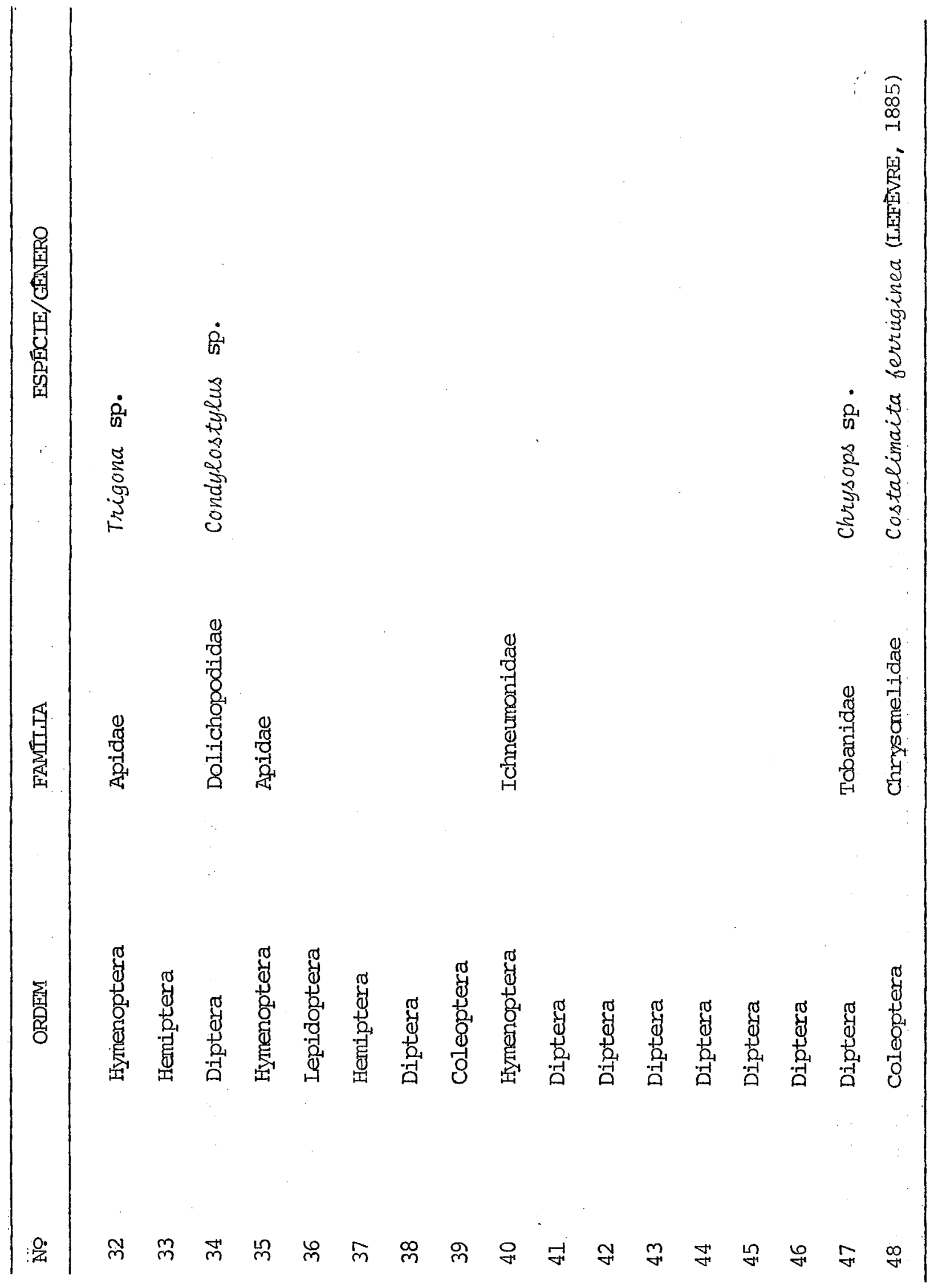



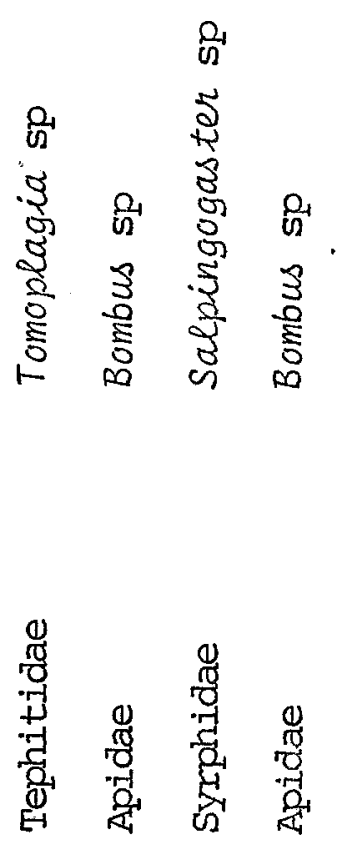

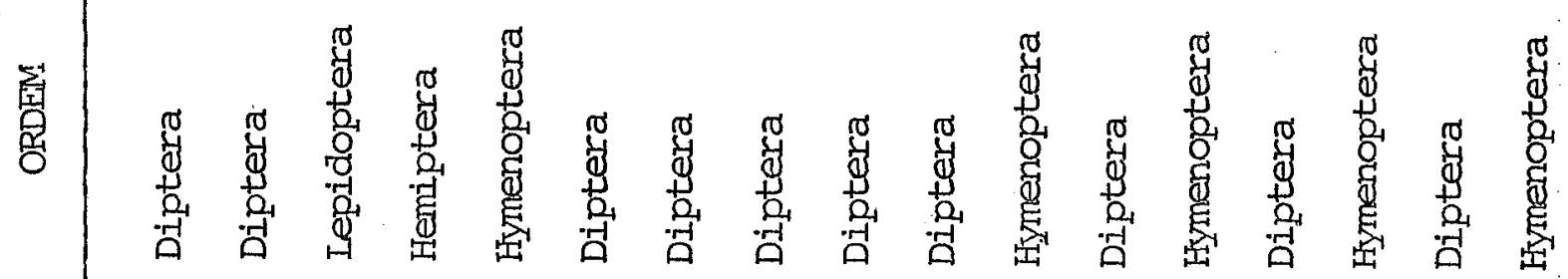

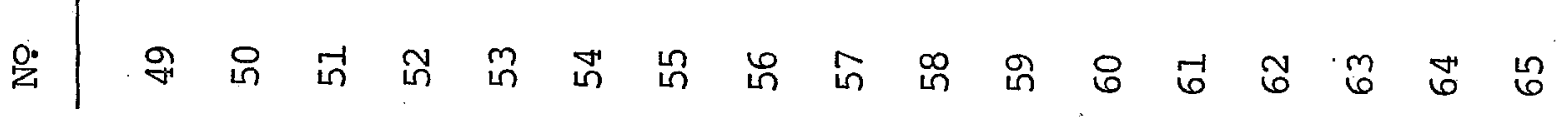




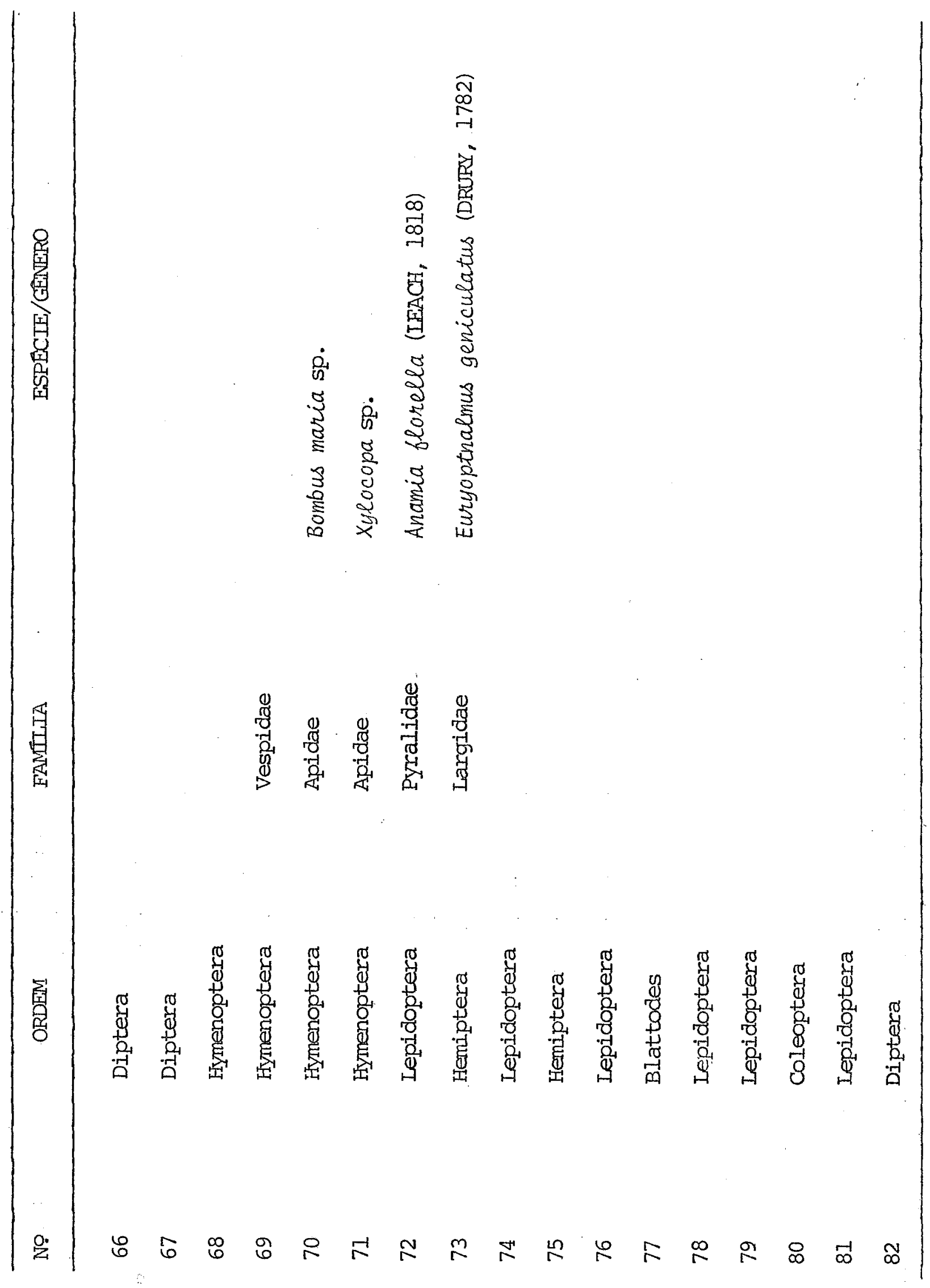




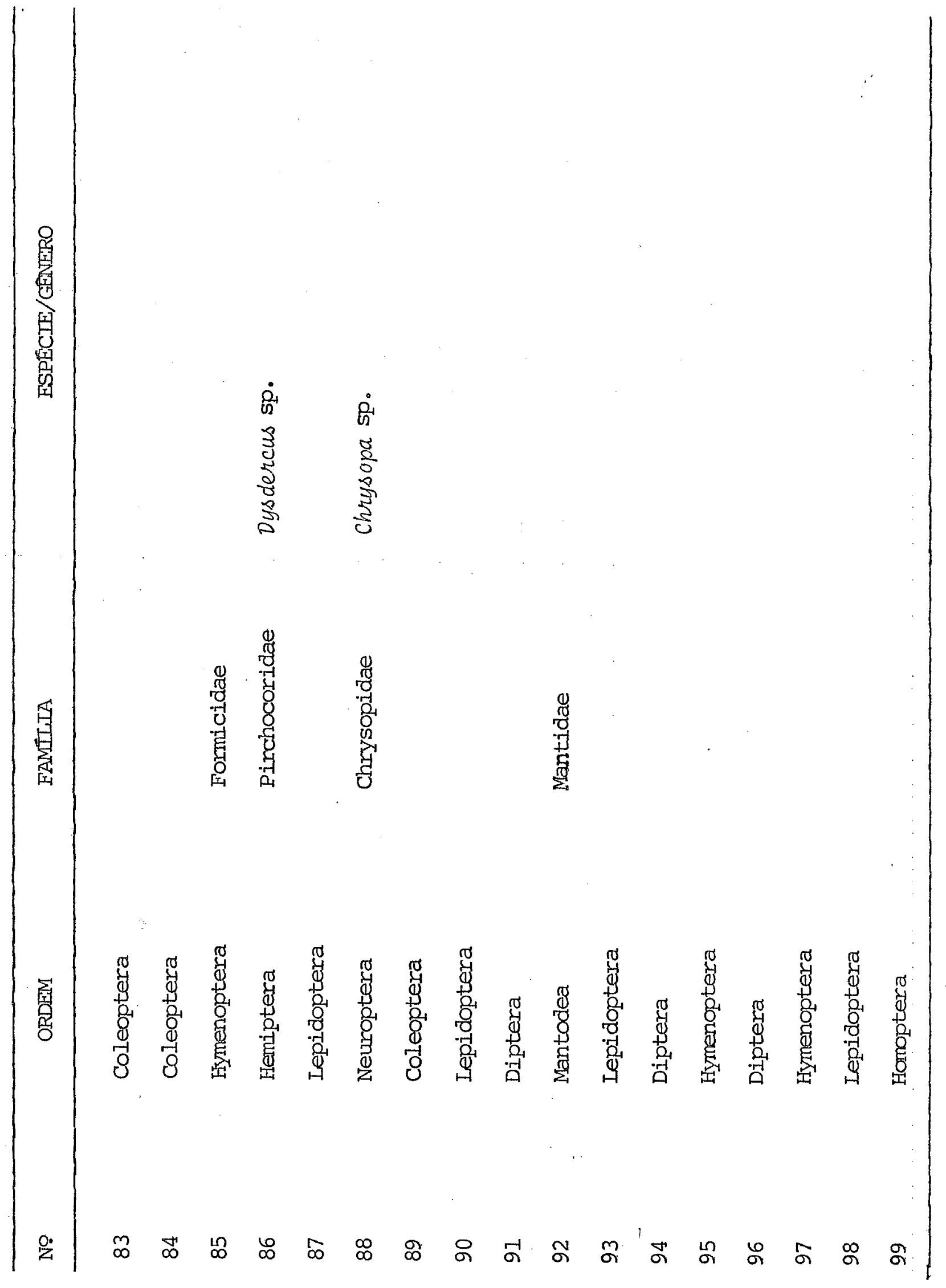




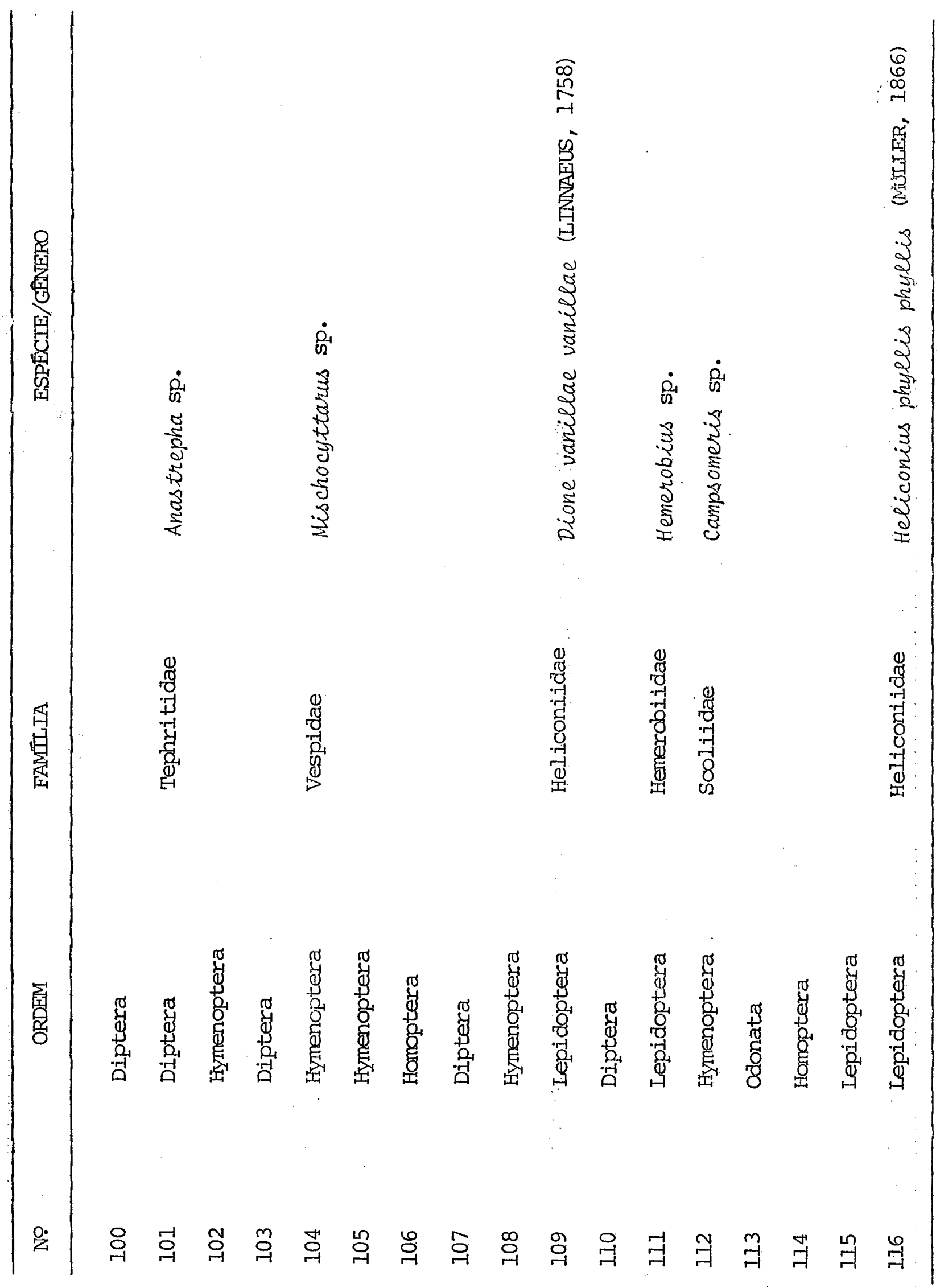


.91.

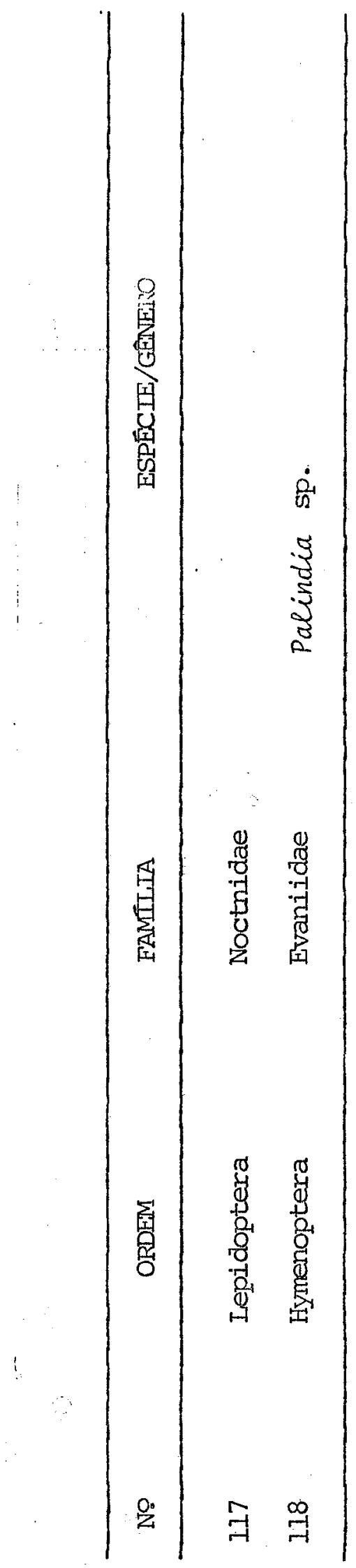

